\title{
Age modelling of late Quaternary marine sequences in the Adriatic: Towards improved precision and accuracy using volcanic event stratigraphy
}

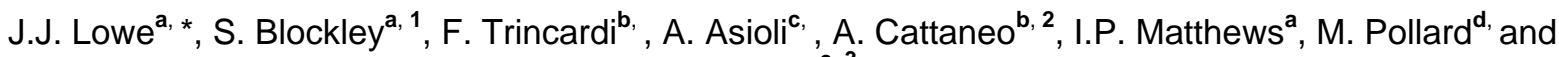 \\ S. Wulf ${ }^{\mathrm{e}, 3}$
}

a Department of Geography, Centre for Quaternary Research, Royal Holloway, University of London, Egham, Surrey, TW20 OEX, UK

${ }^{\mathrm{b}}$ Istituto di Scienze Marine (C.N.R.), Sezione di Geologia Marina, via Gobetti 101, 40129 Bologna, Italy

${ }^{c}$ Istituto di Geoscienze e Georisorse (C.N.R.), Sezione di Padova, C.so Garibaldi 37, 35137 Padova, Italy

d Research Laboratory for Archaeology, University of Oxford, Dyson Perrins Building, South Parks Road, Oxford OX1 3QY, UK

e GeoForschungsZentrum Potsdam, Section 3.3, Climate Dynamics and Sediments, Telegrafenberg, D-14473 Potsdam, Germany

${ }^{1}$ Present address: BLOCKLEY \& POLLARD: Research Laboratory for Archaeology, University of Oxford, Dyson Perrins Building, South Parks Road, Oxford OX1 3QY, UK.

2 Present address: IFREMER, DRO/GM BP 70, 29280 Plouzané, France, tél. : 33-298-224572. Antonio.Cattaneo@ifremer.fr

${ }^{3}$ Present address: Institute for Geophysics, Jackson School of Geosciences, The University of Texas at Austin, PO Box 7456, Austin, TX 78713, USA.

*: Corresponding author : J. J. Lowe, Tel. : +44 1784443563 ; fax : +44 1784472836.

email address: j.lowe@rhul.ac.uk

\begin{abstract}
:
The first part of this paper presents a review of the problems that constrain the reliability of radiocarbon-based age models with particular focus on those used to underpin marine records. The reasons why radiocarbon data-sets need to be much more comprehensive than has been the norm hitherto, and why age models should be based on calibrated data only, are outlined. The complexity of the probability structure of calibrated radiocarbon data and the advantages of a Bayesian statistical approach for constructing calibrated age models are illustrated. The second part of the paper tests the potential for reducing the uncertainties that constrain radiocarbon-based age models using tephrostratigraphy. Fine (distal) ash layers of Holocene age preserved in Adriatic prodelta sediments are analysed geochemically and compared to tephras preserved in the Lago Grande di Monticchio site in southern Italy. The Monticchio tephras have been dated both by radiocarbon and varve chronology. The importance of basing such comparisons on standardised geochemical and robust statistical procedures is stressed. In this instance, both the Adriatic and Monticchio geochemical measurements are based on wavelength dispersive spectrometry, while discriminant function analysis is employed for statistical comparisons. Using this approach, the ages of some of the Adriatic marine ash layers could be estimated in Monticchio varve years, circumventing some of the uncertainty of radiocarbon-based age models introduced by marine reservoir effects. Fine (distal) ash layers are more widespread and better preserved in Mediterranean marine sequences than realised hitherto and may offer much wider potential for refining the dating and correlation of Mediterranean marine sequences as well as marineland correlations.
\end{abstract}

Keywords : Radiocarbon-based age models; Tephrochronology; Volcanic event stratigraphy; Lago Monticchio record; Bayesian method; WDS geochemical data; Discriminant function analysis (DFA) 


\section{Introduction}

Accurate dating and correlation are essential for the construction of reliable models of sediment architecture and influx rates in marine basins, as well as for establishing the links between changes in sedimentation and palaeoenvironmental events. In recent years, the survey and analytical tools employed in the investigation of marine sequences have become more sophisticated, increasing the precision with which palaeoenvironmental records can be assessed. At the same time, analysis of Greenland ice cores (e.g Alley et al., 1993; Dansgaard et al., 1993; North Atlantic Ice Core Project Members, 2004; Rasmussen et al., 2005) has shown that environmental changes during the late Quaternary were much more abrupt than previously understood, with some marked changes in climate possible within a few decades. These developments have fuelled a demand for greater geochronological precision in the analysis of marine sedimentary sequences, to support better resolved palaeoenvironmental records. The question arises, however, as to whether available geochronological methods can deliver this increased precision.

The method most routinely employed to date marine fossils and sediments spanning the last ca. 50,000 years is radiocarbon dating. It is now evident that this method cannot normally provide age estimates for Holocene events at greater than a centennial precision, while true uncertainties of the order of millennia will commonly constrain dates for pre-Holocene events (see below). In this paper we explain why conventional procedures for the construction of radiocarbon-based age models are less secure than has been commonly assumed, and why the wider application of tephrostratigraphy, the basis of a regional Event Stratigraphy scheme, can yield more reliable results.

The discussions focus on records from the Adriatic Sea, as the views expressed here have emerged from workshop activities conducted within the EU-funded EURODELTA and EUROSTRATAFORM projects. The general bathymetric and geographical context of the study area, as well as locations of all cores and sites referred to in the text, are shown in Figure 1. One of the key aims of these collaborative initiatives was the development of more robust age models to underpin precise correlations of marine sediment sequences in various sectors of the Mediterranean, including the Adriatic Sea. However, the recommendations developed below have much wider application to the dating of marine sequences in general.

\section{2. Interpretation of radiocarbon-based age models}

\subsection{Limitations of radiocarbon dating}

Four general sources of uncertainty constrain the precision and accuracy of radiocarbon dates obtained from marine samples : (1) analytical (laboratory) precision; (2) factors affecting the geological (stratigraphical) integrity of dated materials; (3) marine reservoir errors; and (4) calibration procedures. Each of these is discussed in turn. 


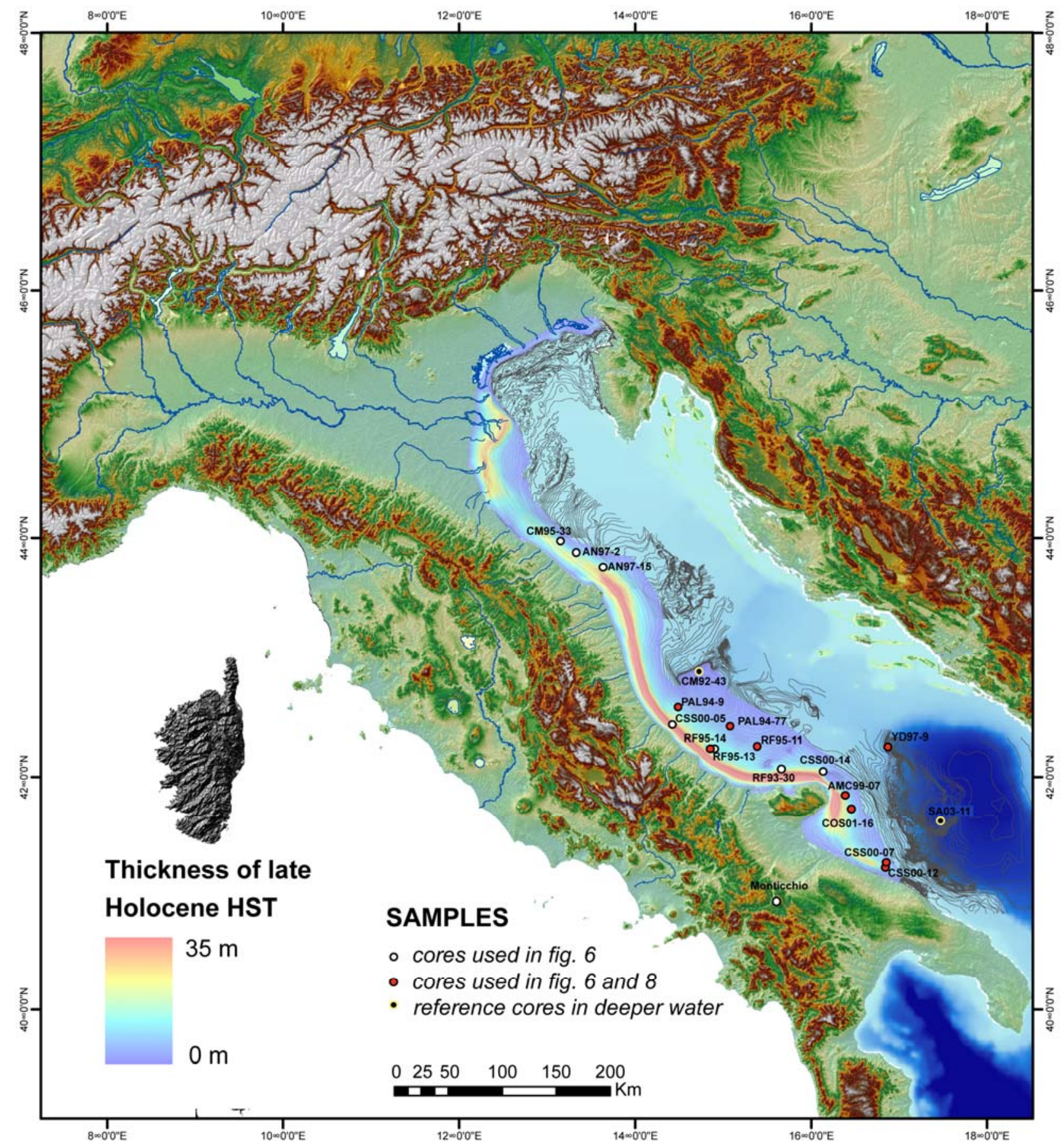

FIGURE 1: Bathymetric and geographical details in the study area, and locations of all cores referred to in the text. 


\subsubsection{Analytical (laboratory) precision}

The $1 \sigma$ analytical error ranges for most conventional radiocarbon measurements are commonly of the order of 80 to 150 (i.e. \pm 40 to \pm 75 ) radiocarbon years, which limits the potential to date events with a high temporal resolution. It is still the case that many age models used in studies of Late Quaternary marine sequences are based on radiocarbon, and that evaluation of the validity of the models usually only addresses the laboratory (activity measurement) precision errors, perhaps because they are readily expressed in mathematical terms. However, these values should not be regarded as indications of the accuracy of the age estimates. A sample submitted to a radiocarbon laboratory which contains a mix of organic materials of different age resulting, for example, from geological or laboratory contamination, will yield a spurious radiocarbon 'age', being an average of the radiocarbon activities of the various components. The activity of such 'mixed' samples can, nevertheless, be determined extremely precisely if the organic carbon content is high. Hence high precision does not of itself indicate reliability. The geological integrity of samples must always be evaluated independently, though contamination of samples may not always be readily apparent, and its effects difficult to define statistically.

\subsubsection{Geological or stratigraphical integrity of samples}

When selecting samples or fossils from sedimentary archives for radiocarbon dating, it is generally assumed that the constituent carbon in each dated horizon is contemporaneous with the time of sediment accumulation. This is unlikely to always be the case, as no sediment horizon is a closed system. In the case of lake sediments, carbon content may be affected by a number of site-specific influences (Lowe \& Walker, 2000), including, for example, 'hard-water' effects which reduce ${ }^{14} \mathrm{C}$ activity, leading to ages that are older than expected - i.e. giving an 'apparent age'. The problem of apparent age is prevalent in the marine realm, but the main causes in this context are ocean circulation processes and variations in the rate of carbon exchange between the oceans and the atmosphere. The resulting 'marine reservoir error' is probably the most serious and widespread source of error affecting radiocarbon dates obtained from marine samples. 
Other factors that may complicate the interpretation of radiocarbon age models are fossil recycling (reworking), contamination during coring or other sampling procedures, and isotopic fractionation. It is widely assumed that these problems can be circumvented by carefully selecting specific types of macrofossil for dating - as, for example, the selection of specimens of a single species of planktonic foraminifera (e.g. Bard et al., 2000, 2004a; Waelbroek et al., 2001). Even very small fossils can now be dated using AMS methods, which are able to generate reasonable measures of ${ }^{14} \mathrm{C}$ activity from as little as $10 \mathrm{mg}$ of organic carbon. In these cases, however, it becomes even more imperative to test for the possibility of contamination, since minute amounts of modern carbon could significantly distort the results. Furthermore, small fossils may be mobile in the sediment column (see e.g. Turney et al., 2000) and hence radiocarbon data-sets based on selected macrofossil samples are not necessarily superior to those based on bulk sediments. The integrity of the results generated by both approaches needs to be tested.

\subsubsection{The 'marine reservoir error'}

The marine reservoir effect is an off-set in ${ }^{14} \mathrm{C}$ age between organisms that derive their carbon from the marine environment and contemporaneous terrestrial organisms (Ascough et al., 2005). It is caused by a combination of (a) slow mixing of ocean waters, (b) temporal variations in the rate of exchange of $\mathrm{CO}_{2}$ between the ocean surface and the atmosphere (e.g. Alley and Clark, 1999; Kanfoush et al., 2000; Hughen et al. 2004), and (c) upwelling of ${ }^{14} \mathrm{C}$-depleted waters near some coasts (Mangerud and Gulliksen, 1975; Goodfriend and Flessa, 1997). The modern reservoir effect in near-surface ocean waters generally varies between about 200 and more than $750{ }^{14} \mathrm{C}$ years and averages around $400{ }^{14} \mathrm{C}$ years. Until comparatively recently, a standard correction of 400 years $\left(\mathrm{R}_{\mathrm{t}}\right)$ was applied to marine-based radiocarbon age estimates. More recent evidence has shown, however, that modern ocean surface reservoir ages vary with latitude and circulation effects. Evidence of marked regional departures from $\mathrm{R}_{\mathrm{t}}$ has led to efforts to define local correction factors, which are expressed as deviations from $R_{t}$, termed $\Delta R$ (Reimer and Reimer, 2001; see http:/www.calib.org). Marine radiocarbon data-sets are now routinely adjusted using regional $\Delta \mathrm{R}$ correction values (e.g Hutchinson et al., 2004). Asioli et al. (1999), for example, suggested c. $170{ }^{14} \mathrm{C}$ years to be an appropriate $\Delta \mathrm{R}$ for samples from 
the Adriatic, while Siani et al. (2000) suggested a value much closer to $R_{t}$ as appropriate for other parts of the Mediterranean.

The practice of defining regional $\Delta \mathrm{R}$ values is not straightforward. Although broad spatial trends are evident at the global scale, variations in modern ocean surface ${ }^{14} \mathrm{C}$ activity can appear random when viewed at the regional scale (Reimer and Reimer, 2001). The reservoir 'age' of the modern Mediterranean surface, for example, generally varies between 280 and $665{ }^{14} \mathrm{C}$ years, but also records values well in excess of 1,000 ${ }^{14} \mathrm{C}$ years. Furthermore, marine reservoir effects have not remained constant over time (Sikes et al., 2000; Bard et al., 1994; Austin et al., 1995; Voelker et al.,1998). Siani et al. (2000) reported significant temporal variations in the magnitude of the marine reservoir effect in the Mediterranean Sea during the recent past. Finally, samples from deep water basins tend to have large reservoir errors, while the gradient in radiocarbon age between surface and deep waters may also have varied over time (e.g. Shackleton et al., 1988; Sikes et al., 2000). All of these effects provide valuable insights into changes in ocean circulation and climate (Ascough et al., 2005), but make radiocarbon-based age modeling extremely problematic.

\subsubsection{Calibration}

The internationally-accepted standard model for radiocarbon calibration, INTCAL04 (Reimer et al., 2004), is based upon radiocarbon-dated tree-ring samples for the sector that extends from the present back to ca. 11.9 kyr (tree-ring yr) BP. Although the use of tree-ring samples provides the most rigorous calibration data available, calibration of Holocene radiocarbon dates is not without problems, due principally to short-term oscillations in atmospheric radiocarbon content (e.g. Van Geel et al., 2003). The highest level of calibration precision for Holocene events is achieved by obtaining multiple radiocarbon dates and matching the temporal trends in the resulting data to the tree-ring based calibration curve (radiocarbon 'wiggle-matching' - see e.g. Van Geel and Mook, 1989; Kilian et al., 2000; Blaauw et al., 2004). Even when this approach is successful, statistical uncertainties remain, and it seems highly unlikely that these procedures can ever provide a precision better than centennial when using relatively low sample numbers 
and INTCAL04 (Telford et al., 2004 a, b). Hence, no matter how rigorously radiocarbon data are treated, the fact remains that calibration frequently introduces an additional error term, over and above those associated with laboratory precision and uncertain geological context. By the rules of combination of statistical errors, calibration will normally reduce the precision of age estimates quite substantially and not, as some practitioners appear to believe, the opposite. In theory, however, it does provide more accurate age estimates, in that the uncertainty ranges are more realistic (more likely to encompass true age).

The uncertainties introduced by calibration increase dramatically in the case of radiocarbon age estimates older than Holocene. The part of the INTCAL04 calibration data-set which dates between approximately 15,585 and 11,500 years BP (the 'Lateglacial' period) is primarily based on radiocarbon-dated laminated sediments from the Cariaco Basin (tropical Atlantic) (Hughen et al. 2004; Reimer et al., 2004). Beyond $15,585 \mathrm{cal}$ BP, and extending back to approximately 24,000 year BP, INTCAL04 is based on paired ${ }^{14} \mathrm{C} / \mathrm{U}$-series dates obtained from corals. The radiocarbon dating of this part of the INTCAL04 data-set is thus based predominantly on marine samples which may be affected by a marine reservoir error. Although there is some reason for believing that this error may not have varied significantly during the last 25,000 years or so (Hughen et al., 2004), this is by no means certain. Calibrating radiocarbon dates of Lateglacial age using INTCAL04 therefore introduces uncertainties, the magnitude of which are difficult to assess at present, but they are likely to exceed those associated with Holocene age estimates, and could well be millennial in scale (e.g. Blockley et al., 2004).

Problems of calibration are even more acute for radiocarbon ages greater than ca. $25 \mathrm{kyr}$ BP. A number of attempts have been made to secure reliable calibration of the radiocarbon timescale back to about $50 \mathrm{kyr} \mathrm{BP}$, based on a range of sedimentary archives. These include the varved sediment sequences preserved in the Cariaco Basin (Hughen et al., 2004) and Lake Suigetsu, Japan (Kitigawa and Van der Plicht,1998, 2000), emerged coral reef formations in the raised coastal terraces of New Guinea (Yokoyama et al., 2000), speleothem carbonate from submerged caves in the Bahamas (Beck et al., 2001) and Bermuda (Chiu et al., 2005), a sequence of aragonitic lake sediments from Lake 
Lisan in Israel (Schramm et al. 2000), and deep marine sediment sequences that can be matched with ice-core records using assumed synchronous palaeoenvironmental events (Voelker et al., 1998; Bard et al., 2004a). There are marked differences between these calibration models, partly because the dated material is of such antiquity that it contains very small mounts of residual ${ }^{14} \mathrm{C}$ and hence precisions are low. The reliability of the models is therefore difficult to test at present. Until this matter is resolved, calibration of radiocarbon dates older than ca. 25 kyr BP will introduce uncertainties that are millennial in scale (Bard et al., 2004a, 2004b).

\subsection{Radiocarbon-based age models}

The chronology of a suite of sediments that falls within the range of radiocarbon dating is generally determined by generating a series of radiocarbon age estimates from selected horizons to construct an age-depth curve or age model (e.g. Figure 2). Procedures for constructing an age model from the data vary, depending upon the degree of 'scatter' in the results. The simplest approach is to join the mean values of individual dates and assume a linear sedimentation rate between each dated horizon. For complex data-sets distorted by a number of age reversals, this procedure is not straightforward. In such cases, quite arbitrary decisions often have to be made which may involve rejecting or down-weighting some of the values because they are regarded as 'outliers' with respect to some hypothesised general trend, such as a polynomial regression (Figure 2; see e.g. Asioli et al., 1999; Walker et al., 2003).

Employing such procedures underestimates the statistical limitations in the data, however, especially if the data are analysed using the radiocarbon timescale. Six key limitations that need to be considered are as follows. First: if the radiocarbon dates are defined with a $1 \sigma$ precision, then it follows that the true ages of about one third of the age estimates will lie outside the given error ranges, making the practise of joining mean values highly questionable. Using a $2 \sigma$ precision increases accuracy, but reduces precision. Second: a coherent age-depth plot generated from the data does not 


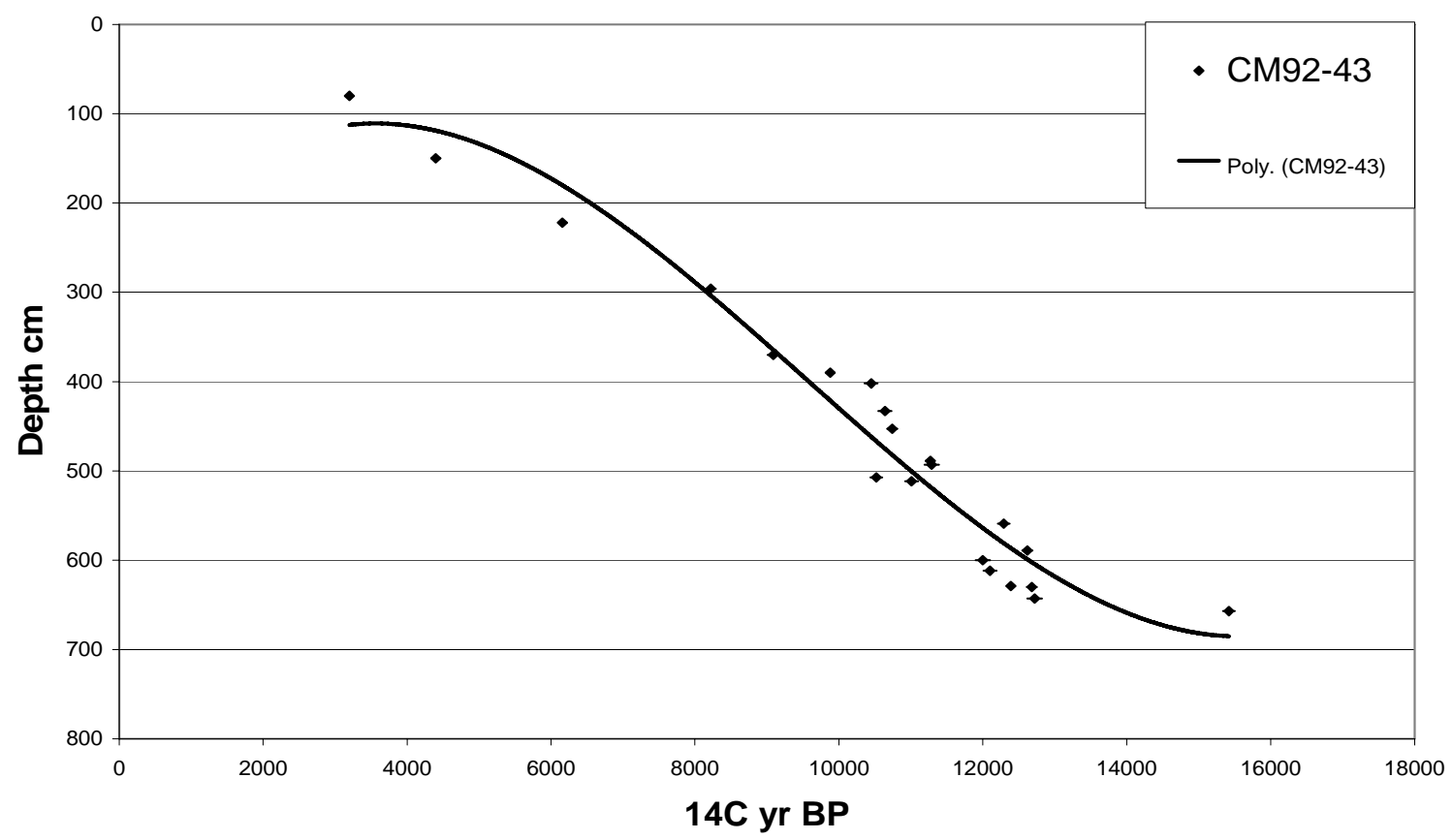

FIGURE 2: Age-depth plot with polynomial regression trendline for radiocarbon measurements obtained for marine core sequence CM92-43, located in the central Adriatic (for location and other contextual details, see Figure 1, Asioli et al., 1999, Blockley et al., 2004).

necessarily mean that the age-depth relationship is as straightforward as might appear, or that the mean radiocarbon ages can be taken as reliable indicators of age. The validity of this approach depends upon the number of age estimates obtained for the period under investigation, which partly determines the temporal precision with which events can be resolved. If a low number of dated points is available, and the magnitude of the differences in mean age between dated horizons exceeds that of the error ranges of the individual dates, then a generalised age-depth plot may well be valid, though it would be a crude model at best. The higher the temporal resolution attempted, the more difficult it becomes to resolve a reliable age-depth relationship, since the magnitude of the uncertainties of individual age measurements may exceed the time intervals between dated horizons. This problem will be compounded further by geological (sample integrity) and calibration uncertainties. 
Third: assumptions of linear sedimentation rates between dated horizons are unlikely to be valid, especially in the case of sediments that have accumulated during episodes of pronounced climatic change. The more widely spaced the dated horizons in a series, the more questionable this practice becomes. Linear or polynomial smoothing of the data are perhaps even more subjective, because more sweeping assumptions about rates of sedimentation and bioturbation become necessary.

Fourth: the practice of excluding apparent 'outlier' values on the grounds that they do not conform to a perceived regular age-depth relationship is invalid if the data are plotted on the radiocarbon timescale, because that timescale is not linear. The true age-depth relationship of a series of radiocarbon dates cannot be established unless the data have been calibrated. Individual radiocarbon age estimates can have several alternative calibrations due to the pronounced 'wiggles' in the radiocarbon calibration curves, while age estimates that appear to be in inverted order when plotted in radiocarbon time may not remain so when plotted in calibrated time (Bowman, 1990; Buck et al., 1991; Buck and Christen 1998; Blockley et al., 2004).

Fifth: an individual radiocarbon age estimate amounts to a single estimate of the statistical variance in radiocarbon activity that characterises each sampled horizon. Unless several independent age estimates are obtained, the variance in radiocarbon activity for that horizon remains unknown, and hence the validity of a single radiocarbon measurement will be difficult to test. Several recent studies have shown how an increase in the number of age estimates obtained, coupled with the dating of different organic components, leads to more comprehensive assessments of the 'radiocarbon inventory' preserved in sediment sequences, and a more secure basis for age modelling (e.g. Turney et al., 2000; Walker et al., 2001; Lowe et al., 2004).

Sixth: perhaps the most crucial constraint affecting radiocarbon-based age models is the effect of calibrating the data. Calibration introduces two significant difficulties. The first, already alluded to, is a markedly reduced precision due to uncertainties in available 


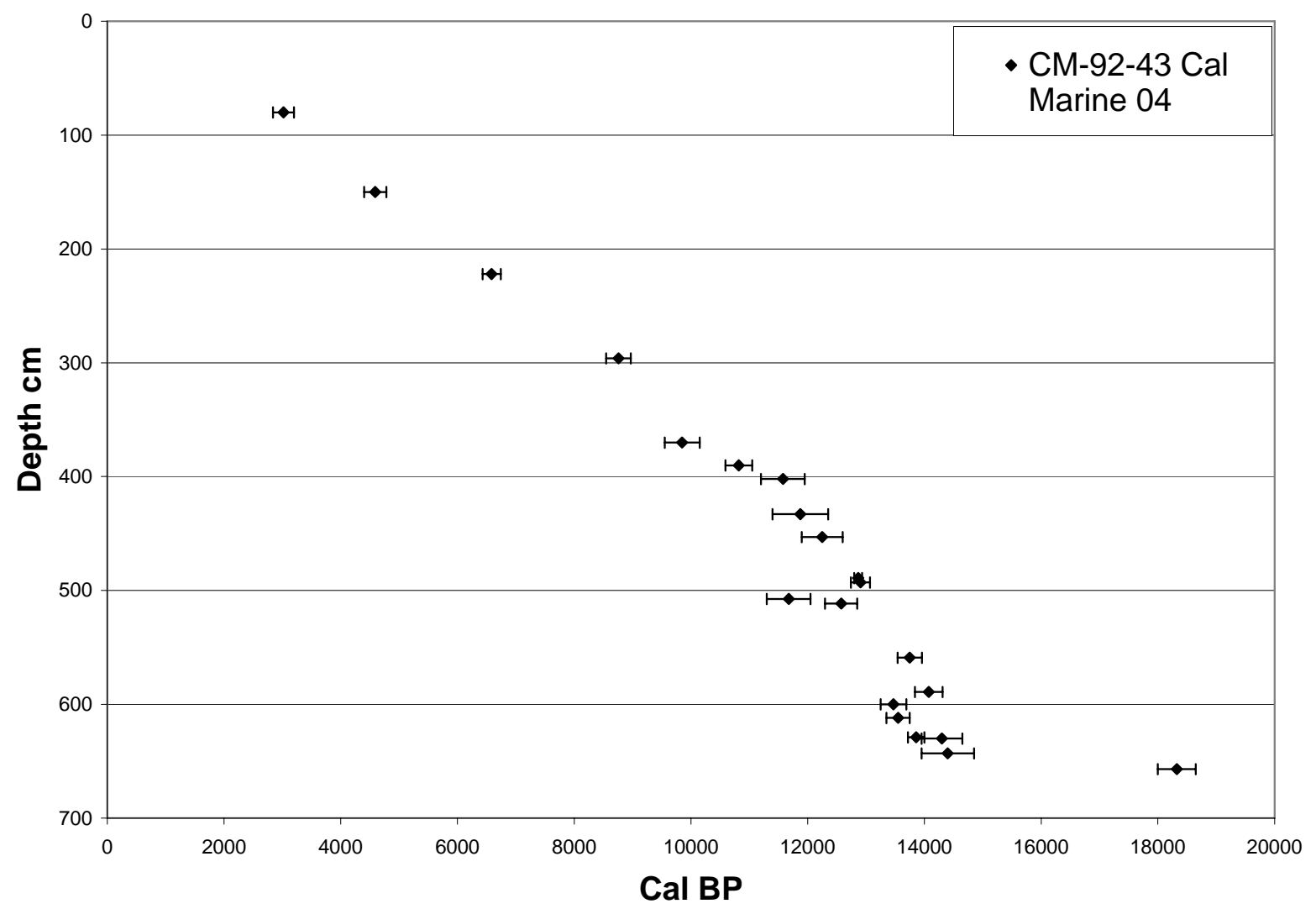

FIGURE 3: The uncertainty ranges of the INTCAL04 calibration plots of the $2 \sigma$ probability ranges of the CM92-43 radiocarbon dates.

calibration models. This problem is especially acute for pre-Holocene data, as illustrated in Figure 3, which reveals the increased error ranges after calibrating the data of Figure 2. The second concerns the evaluation of the probability structure of a series of calibrated radiocarbon dates. Radiocarbon dates are Gaussian in structure, but the calibration curve is non-Gaussian, and statistically complex, reflecting sudden variations in atmospheric ${ }^{14} \mathrm{C}$ content that are not fully understood or predictable (Taylor et al., 1992). As a result, a radiocarbon date with a well defined mean and single mode (Gaussian distribution) will frequently 'translate' in calibrated time to a more complex probability spectrum, usually with several modes, and no straightforward way of assessing highest likelihood (Figure 4). Where age models from two or more sites are being compared, the mathematical relationships in the data can be highly complex. Increasingly, practitioners are turning to 


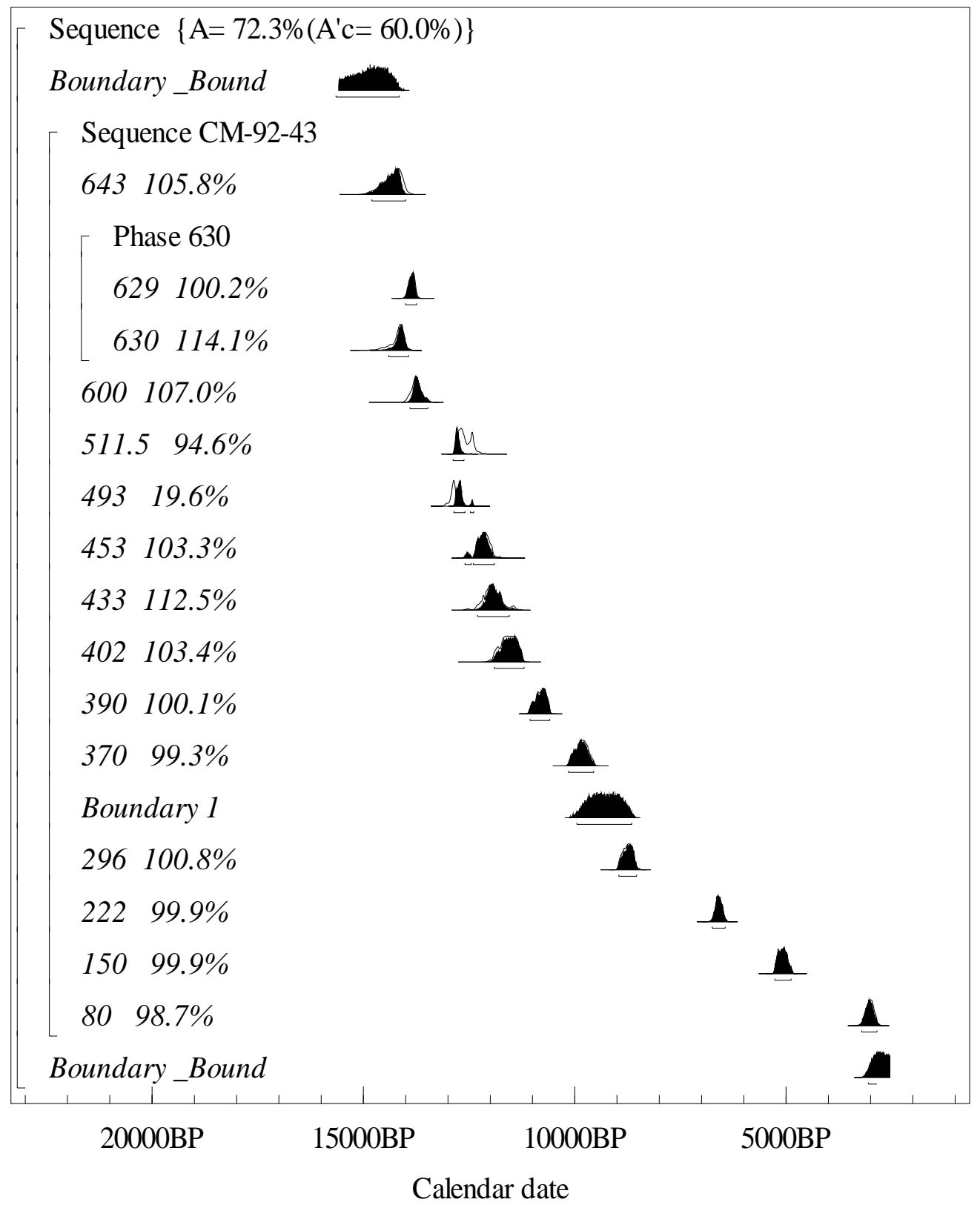

FIGURE 4: Bayesian age modeling output for core CM92-43 radiocarbon data using stratigraphical position to constrain the Highest Probability Density for each date. The data were calibrated using the INTCALMarine04 model with no $\Delta \mathrm{R}$ off-set. Boundaries applied during data analysis are mathematical constructs calculated from all of the ages in the sequence and applied in order to constrain the computations to a finite time-slice (see Blockley et al., 2004). Percentages to left are agreement indices calculated from the level of overlap between the original calibrated density functions (clear histogram) and the Highest Probability Density output (shaded histogram) resulting from Markov Chain Monte Carlo simulations. 
the use of more sophisticated statistical tools for analysing such data, such as the Bayesian probability approach.

\subsection{Optimising age-depth models and correlation schemes}

While the difficulties outlined in earlier sections of this paper raise serious questions about the limits of precision and accuracy achievable with radiocarbon-based age models, there are realistic expectations that the position will markedly improve in the near future. Calibration models should become much more tightly constrained when continuous treering series are extended beyond 11,900 cal BP (e.g. Friedrich et al., 2001; Kromer et al., 2004). Our understanding of temporal variations in atmospheric ${ }^{14} \mathrm{C}$ concentration may benefit from new studies of temporal variations in abundance of other cosmogenic nuclides, such as ${ }^{10}$ Be (e.g. Beer et al., 2002; Muscheler et al., 2004). In due course, a fuller understanding of the spatial and temporal variations in marine reservoir effects can also be anticipated, leading to refined reservoir corrections. However, these developments will be undermined if the raw radiocarbon data-sets to which they are applied are themselves inadequate; there is a parallel need, therefore, for more robust and better constrained radiocarbon data-sets to underpin calibration exercises and any age models derived from the results. Three refinements that could readily be employed to achieve this are as follows.

First: an increase in the number of radiocarbon age estimates used to underpin each site investigation, sufficient to allow rigorous assessment of any statistical trends in the dataset, is essential (Bennett, 1994). Most published site chronologies for the Mediterranean region are inadequate in this respect. A data-bank of all radiocarbon-based site chronologies relevant to the EURODELTA Concerted Action project, in total comprising some 600 radiocarbon dates obtained from 260 marine Mediterranean sequences

spanning the late Quaternary (last 25,000 years or so), revealed that only 4 site chronologies consisted of 10 or more radiocarbon dates. The most robust series was that obtained for site CM92-43 in the Adriatic (Figure 2). Given the relatively low precisions associated with most of these dates, collectively the results offer little more than 
'rangefinder' capacity (i.e. no better than a millennial resolution). For substantially better constrained age models, many more age estimates would be required. As a useful guide, Telford et al. (2004b) conclude that, in order to achieve a true centennial resolution, around 24 dated horizons would be needed from a typical Holocene series to reduce statistical noise to a level where meaningful smoothing splines could be fitted to the data. Few published radiocarbon data-sets from the Mediterranean region are that robust.

Second: without some analysis of the degree of variance that characterises dated horizons, it can be difficult to determine which age estimates are reasonably reliable and which are aberrant values. In Figure 2, for example, two ‘clusters' of dates are evident that are difficult to interpret without some objective basis for determining reliability. Constructing an age-depth model through such data entails arbitrary decisions, and the less robust the data-set, the more subjective the exercise becomes. Increasing the number of age measurements to test for replication might reduce the statistical scatter, though it could well result in the opposite, if there has been significant sediment mixing. This would be a costly exercise, however, without any guarantee of success. Nevertheless, if the objective is to generate age models that are both accurate and precise, then this problem of sample heterogeneity needs to be confronted. Perhaps resources could be focused on tests of the statistical reliability of age models developed for particularly important sequences, such as regional type sites, or of the validity of reconstructions that suggest unusually abrupt changes in sedimentation rate or apparent age reversals.

Third: though calibration of radiocarbon dates increases statistical uncertainty, it is nonetheless essential. The true age-depth structure of a series of radiocarbon dates can only be tested in calibrated ('real') time, because of the non-linearity of the radiocarbon timescale. Interpreting the results requires the deployment of sophisticated statistical procedures, such as Bayesian methods, to cope with the non-Gaussian probability distributions of calibrated data-sets (for explanation of this approach see e.g. see Buck et al., 1991; Buck \& Blackwell, 2004; Christen et al., 1995; Blockley et al., 2004). An attempt to apply Bayesian analysis to the CM92-43 radiocarbon data-set (Figure 5; Table 


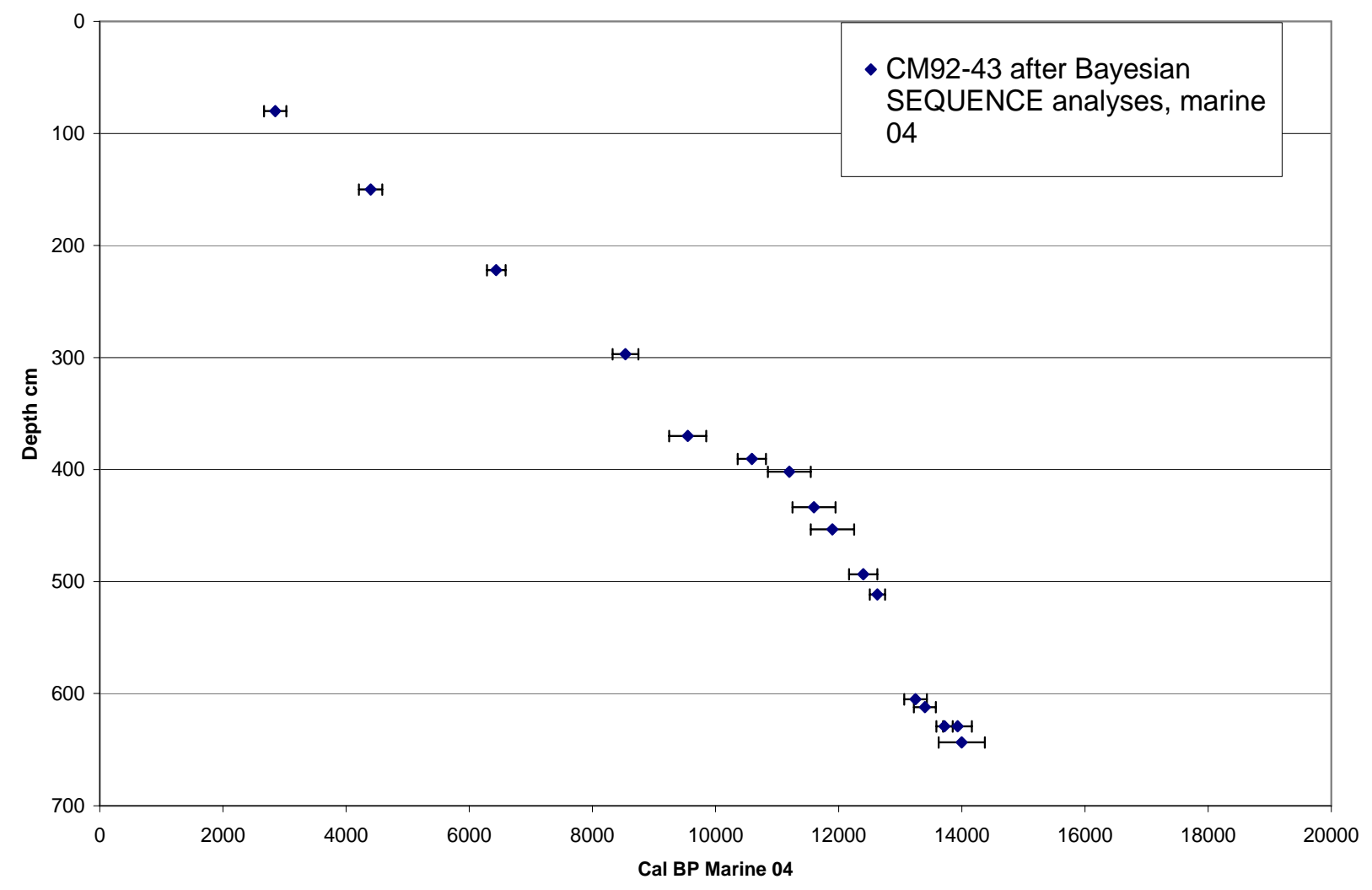

FIGURE 5: Calibrated age-depth model for CM92-43 using the Bayesian package within OXCAL and the INTCAL04 calibration data-set.

1) illustrates the procedure, but also the limitations that existing Mediterranean data-sets present when adopting this approach.

A Bayesian form of Markov Chain Monte Carlo analysis was applied to the CM92-43 radiocarbon data using the INTCAL04 calibration model, the OXCAL software (Bronk Ramsey, 1999) and a prior rule that age must increase with sediment depth. The method tests sequentially through all possible combinations for the highest probability match between (i) the sub-set of the CM92-43 radiocarbon data-set that best obeys the prior rule and (ii) the INTCAL04 calibration model. The probability distribution of individual radiocarbon age measurements are treated independently in the analysis, so that the outcome is not based on knowledge of the other radiocarbon dates in the set, or on a prejudgment of the order in which the dates should plot; the data only need satisfy the prior 


\begin{tabular}{|c|c|c|c|c|c|}
\hline \multirow{2}{*}{$\begin{array}{c}\begin{array}{c}\text { Sample } \\
\text { Depth } \\
\text { (cm) }\end{array} \\
78.5-81.5 \\
\end{array}$} & \multirow{2}{*}{$\begin{array}{c}{ }^{14} \mathrm{C} \\
\text { mean } \\
\text { age }(y r)\end{array}$} & \multirow{2}{*}{$\begin{array}{c}\begin{array}{c}\text { lab } \\
\text { error } \\
\text { (yr) }\end{array} \\
60 \\
\end{array}$} & \multicolumn{2}{|c|}{$\begin{array}{l}\text { Calibration error } \\
\text { range (cal yr) }\end{array}$} & \multirow{2}{*}{$\begin{array}{c}\begin{array}{c}\text { sample } \\
\text { typel } \\
\text { event }\end{array} \\
\text { Plank }\end{array}$} \\
\hline & & & 3209.5 & 2849.5 & \\
\hline 150 & 4400 & 60 & 4779.5 & 4399.5 & AMS \\
\hline $220-224$ & 6160 & 60 & 6739.5 & 6439.5 & Plank \\
\hline $295-298.5$ & 8220 & 70 & 8959.5 & 8539.5 & Plank \\
\hline $\begin{array}{c}368.5- \\
371.5\end{array}$ & 9090 & 80 & 10149.5 & 9549.5 & Plank \\
\hline $\begin{array}{l}389.5- \\
391.5\end{array}$ & 9880 & 60 & 11049.5 & 10589.5 & Plank \\
\hline $400-404$ & 10450 & 90 & 11899.5 & 11199.5 & Plank \\
\hline $\begin{array}{c}431.5- \\
435.5\end{array}$ & 10640 & 90 & 12299.5 & 11599.5 & Plank \\
\hline $\begin{array}{l}451.5- \\
455.5 \\
\end{array}$ & 10740 & 70 & 12599.5 & 11899.5 & Plank \\
\hline $\begin{array}{l}491.5- \\
495.5\end{array}$ & 11290 & 100 & 12859.5 & 12399.5 & Plank \\
\hline $510-513$ & 11010 & 90 & 12879.5 & 12629.5 & Plank \\
\hline 605 & 12000 & 100 & 13619.5 & 13249.5 & NYT \\
\hline $610-614$ & 12100 & 90 & 13759.5 & 13399.5 & Plank \\
\hline $627-631.5$ & 12390 & 60 & 13989.5 & 13719.5 & Plank \\
\hline $627-631.5$ & 12680 & 70 & 14399.5 & 13929.5 & Plank \\
\hline $\begin{array}{c}641.5- \\
645.5\end{array}$ & 12720 & 100 & 14749.5 & 13999.5 & Plank \\
\hline
\end{tabular}

AMS = Agnano Monte Spina

NYT = Neapolitan Yellow Tuff

Plank = planktic forams

TABLE 1 Calibration errors for the sub-set of radiocarbon dates in the CM92-43 radiocarbon series that provides the optimal match to INTCAL04 following Bayesian analysis of the complete data-set using a Sequence algorithm and uniform prior in Oxcal (Bronk Ramsey,1999). See Blockley et al. (2004) for further explanation.

rule. The appeal of this approach is that it provides an objective test that is independent of stratigraphic assumptions, it employs the full radiocarbon inventory available for each sequence (no data are excluded until analysis is complete) and it makes any data selection explicit. However, precision is markedly reduced when using this method (Table 1), especially with respect to the older dates in the series, partly because of the underlying uncertainties in the INTCAL04 model, but also as a consequence of the relatively low number of dates in the CM92-43 series. Attempts to apply this approach to other radiocarbon data-sets from the Mediterranean yielded highly unsatisfactory results because of the low numbers of dates in each data-set. For better constrained matches to 
the INTCAL04 data-set, therefore, much more robust radiocarbon series are required from sites in the Mediterranean than those that are currently available.

The wider adoption of the steps outlined above should lead to much better constrained radiocarbon-based age models, although testing the validity of the results will remain an issue while the uncertainties in calibration models, as well as those introduced by marine reservoir effects, remain so large. An independent chronometer is needed to test the validity of models and of correlations based upon them. Such a tool is readily available in the Mediterranean region - the routine use of isochronous tephra layers to correlate (tephrostratigraphy) and date (tephrochronology - i.e. when the ages of individual tephra layers are known) marine records.

\section{Testing the reliability of ${ }^{14} \mathrm{C}$ age models using tephrostratigraphy}

\subsection{Scientific context}

Tephra layers are widely encountered within late Quaternary sediment sequences in the Mediterranean, particularly in the central basins (e.g. Keller et al., 1978; Paterne et al., 1988, 1990). They are routinely employed to date and correlate marine records (e.g. Calanchi et al., 1996, 1998; Siani et al., 2004). Some of them can also be traced to terrestrial sites, including lake basins, where they can be reasonably well dated. Of particular note in this respect is the Lago Grande di Monticchio sequence in southern Italy (Figure 1), which spans approximately the last 100,000 years, and which contains a detailed tephrostratigraphical record (a total of 340 tephra layers) for that time-span (Wulf et al., 2004). Annually-laminated sediments are also preserved in this sequence, and hence some of the tephra layers can be dated by both radiocarbon and varve chronology (Brauer et al., 2000). This means that marine records that contain the same tephra layers can be dated indirectly, assuming that the tephras are isochronous and have been identified reliably. This approach offers a distinct advantage for dating marine sequences, since terrestrially-derived age estimates, while not free of problems, are at least unaffected by the distortions caused by marine reservoir effects. Indeed, comparisons between ${ }^{14} \mathrm{C}$ ages obtained from both terrestrial and marine deposits that 
contain the same tephra allows the magnitude of marine reservoir effects to be estimated (e.g. Austin et al., 1995; Blockley et al., 2003; Eiriksson et al., 2004). This approach also provides age estimates for marine sediments that cannot be dated satisfactorily by radiocarbon due, for example, to the absence of suitable organic material.

The potential that tephrostratigraphy offers for constraining radiocarbon-based age models is illustrated in Figure 6, in which the calibrated chronology for CM92-43 (Figure 5) is compared with that from core PAL94-77. Note that the former was derived using Bayesian analysis, whereas insufficient data were available to enable this approach to be adopted in the latter case. Nevertheless, the key point to note is how the options are more tightly constrained when it is known that specific horizons in each sequence must be isochronous. In this example (Figure 6), the Agnano Monte Spina tephra (AMS) and the Neapolitan Yellow Tuff (NYT), dated respectively to approximately 5700-5400 and 14,120 varve years in the Monticchio record (Wulf et al., 2004), are common to both Adriatic sequences, providing common 'pinning points' for evaluating how well the two series match. Clearly, the more tephras that are common to each sequence being compared, the more pinning points that can be used for correlation purposes. This exercise remains worthwhile even when the ages of the tephras are not known, so long as it can be reasonably well established that they represent isochronous events. If the ages of the tephras are known, then this information can be added to the data-sets being analysed by Bayesian probability procedures, which reduces the options when constructing age models. In this way, the error ranges in both age models compared in Figure 6 have been more tightly constrained.

The potential for using tephras for these purposes has greatly increased in recent years with the discovery of very fine distal ash layers in marine sediments, sometimes referred as 'microtephra' or 'cryptotephra' layers (Turney and Lowe, 2001). Consisting of particles of less than c. 80 microns in size, these layers are invisible to the naked eye and hence only detectable when using sensitive laboratory extraction procedures and microscopic examination of sediment residues (Turney et al., 1997; Davies et al., 2002). They have been widely detected in lake sediments throughout Europe, as discrete but 


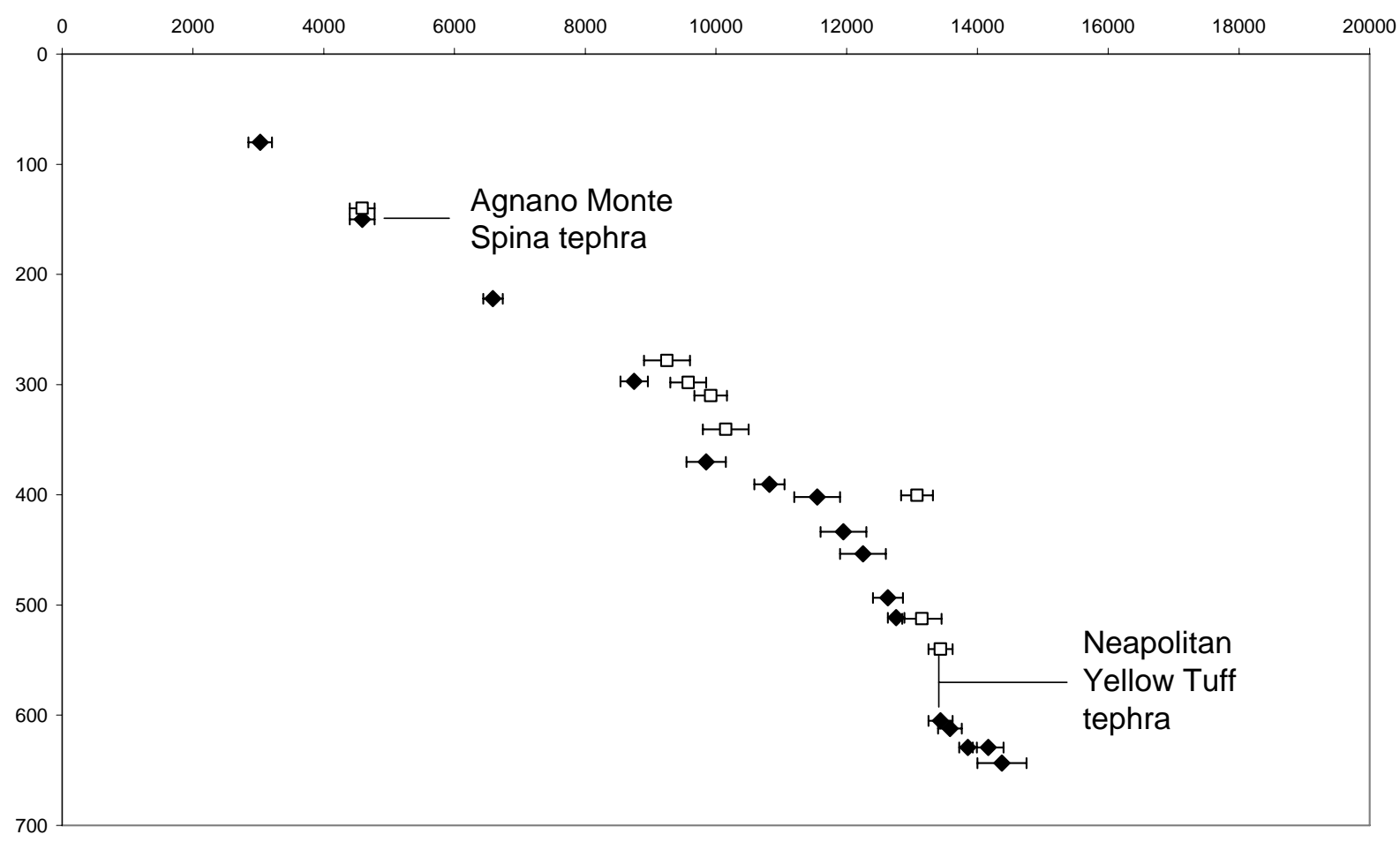

FIGURE 6: Calibrated models for CM92-43 (diamond symbols) and PAL04-77 (squares), constrained after importation of two tephras of known age, the Neapolitan Yellow Tuff (NYT) and Agnano Monte Spina (AMS). Note the reduction in scatter of calibrated age estimates achieved after importation of these data into the Bayesian models.

very thin layers which can be traced to sites that lie far beyond the limits of the corresponding visible ash layers. Some of these distal ash layers have not been associated with visible tephras and may well record additional volcanic events not yet resolved in the proximal tephra record (e.g. Davies et al., 2001; Turney and Lowe, 2001; S. PyneO’Donnell, 2005).

It appears that distal ash layers may be equally widespread in some late Quaternary marine deposits. For example, a deep marine core from site SA03-11 in the Central Adriatic (Figure 1), which spans approximately the last 35,000 years, contains 36 discrete tephra horizons, only 9 of which are visible in the core, the others being non-visible ash layers that were not detected by routine magnetic scanning procedures (Abbott, 2005). Well preserved fine ash layers with distinct peaks in glass shard concentration have also been detected in ocean bottom sequences in various sectors of the North Atlantic 
(Eiríksson et al., 2000, 2004; Haflidason et al., 2000; J.J. Lowe, S.P. O’Donnell et al., unpublished) as well as in shallow marine deposits in the north Adriatic (see below). It appears, therefore, that there is considerable scope for augmenting the marine tephrostratigraphical record in order to increase the number of marker events that can be routinely employed to link marine sequences.

There are clear benefits to be gained from the routine employment of tephrostratigraphy as a complementary tool to radiocarbon dating. There are, however, a number of technical difficulties that need to be addressed. First: several tephras can have very similar chemical signatures, because they have been derived from the same volcanic source. Regular eruptions from the Phlegrean Fields and Vesuvius, for example, have produced tephras of similar chemical composition. The Lago Grande di Monticchio record (Wulf et al., 2004) demonstrates this clearly, particularly for the middle Holocene which appears to have been one of the most volcanically active periods in this region during the last $\sim 100,000$ years. This record shows, for example, that the Agnano Monte Spina tephra, which hitherto was assumed to reflect a single volcanic event (e.g. Di Vito et al., 1999; Dellino et al., 2001, 2004), probably comprises at least four eruptive phases, spanning approximately 1,000 years. The four tephras have very similar chemical signatures, but possibly originate from two different eruptive centres - Agnano Monte Spina and Astroni (Wulf et al., 2004; see below). This presents both an opportunity and a challenge, since on the one hand it increases the temporal resolution with which marine sequences could potentially be compared, while on the other it may not always be possible to establish which event is represented if only one of the four tephras is present.

Second: tephras can be recycled and some may not be represented in the sediment record. The discovery of distal ashes that are not represented in visible tephra records suggests that the history of volcanic activity is incomplete. No single site is likely to contain a full record of the tephras emitted during specific intervals. Some records may be complicated by sediment disturbance and recycling, which can lead to resedimentation of tephras. Exacting analysis may be required to establish the degree to which individual records are afflicted by these problems. 
Third: inconsistent and sometimes imprecise methods are employed to determine the chemistry of individual tephras. Until comparatively recently, Energy Dispersive Spectrometry (EDS) has been the main analytical tool employed to determine the chemical signature of individual tephra layers recovered from marine cores, in part because analysis time is much shorter than is the case with the alternative procedure of WDS (Wavelength Dispersive Spectrometry). Unfortunately, measurement precision is lower for EDS, while the longer exposure to electron beam current can result in significant mobilisation of $\mathrm{Na}$, which distorts the results obtained for element ratios (see Hunt and Hill 2001). This is caused by the unit sum problem, where the proportion of individual elements is calculated as a wt\% of the total of all elements measured, and thus erroneously low values for one element will inflate the values of all of the others. In view of the fact that several tephras can have very similar chemical signatures, analytical precision is critical: practitioners are increasingly finding that EDS data in general, as well as poorly constrained WDS data, are insufficiently precise.

Fourth: tephra chemistries are compared using inconsistent statistical procedures. Practices vary in the criteria used to compare tephra chemical signatures (major element ratios), with little consistency in the use of biplots and/or triplots, or in the elements selected for comparison, which are not necessarily chosen for sound geological reasons. Fifth: tephras are prone to chemical alteration. Insufficient attention has been paid to the fact that glass is an unstable substance. It is prone to chemical alteration in the sediment environment (Pollard et al. 2003), a tendency that may be enhanced in the marine environment (Horwell et al., 2003; Utzmann et al., 2002). Distal ash particles may be susceptible to chemical attack during the application of chemical digestion procedures in the laboratory, due to their delicate nature and high surface-to-volume ratios (Blockley et al., 2005).

Taking these problems together, there is ample scope for misidentification and false correlation in tephrostratigraphy. More secure analytical protocols are required if the method is to achieve its full potential. Reliable stratigraphical type sequences are also 
required, where tephra layers are preserved in unequivocal successive order, and from which robust chemical data can be generated to provide standards for comparison. For the central Mediterranean region, a strong candidate in this respect is the Lago Grande di Monticchio sequence. Here, a number of tephras are preserved in sediments that are finely laminated. Extensive disturbance of these sediments and their contained fine ash layers seem unlikely. Furthermore, chemical analysis of the tephras in this sequence is entirely based on WDS measurements. Finally, a number of the tephras can be assigned varve as well as radiocarbon ages (Wulf et al., 2004).

Next we test the potential for improved tephrostratigraphical correlation of Adriatic sequences and for matching key volcanic events to the Monticchio record. An attempt is made to develop more rigorous analytical and statistical procedures and to apply them to classify fine distal ash layers of early to middle Holocene age which have previously proved difficult to interpret and which therefore provide a stringent test of the methods.

\subsection{Experimental aims}

Figure 7 shows the locations and stratigraphical context of a number of cores obtained from the prodelta sediment wedge that occupies the western margin of the Adriatic. Only a few of the sequences have been studied in detail, but provisional correlations are based on magnetic susceptibility data, rangefinder radiocarbon dates, preliminary analysis of visible tephra layers and key biostratigraphical markers, notably the disappearance of Globorotalia inflata which is a pronounced feature in each record (Asioli, 1996; Trincardi et al., 1996; Oldfield et al., 2003). Collectively, these data are internally consistent, indicating that this segment of the Adriatic prodelta sediment wedge accumulated during the mid- to late Holocene. The question arises, however, as to how far this general stratigraphical picture can be refined, since this will determine the level of sophistication with which sediment accumulation models can be constructed.

It is difficult to provide a well defined answer to this question in numerical terms, since the uncertainties in the methods employed are rather large, and in some instances not easily quantified. Problems constraining radiocarbon-based age models and 

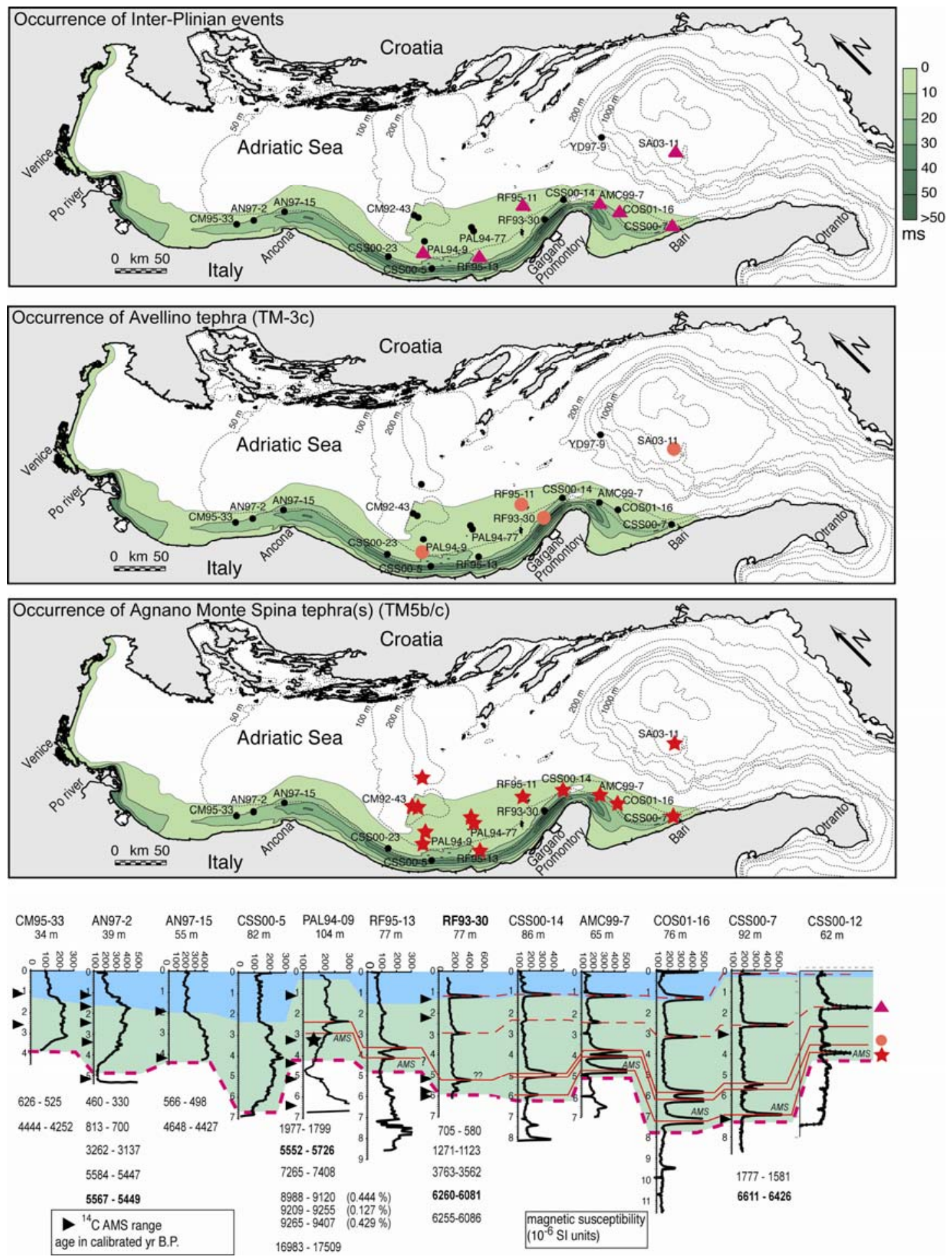

FIGURE 7: Distribution of cores in the prodelta wedge of the Adriatic which record presence of Inter-Plinian (top map), Avellino (middle map) and Agnano Monte Spina (lowest map) tephras. The lowermost diagram shows whole-core magnetic susceptibility records, the positions of visible tephra layers, radiocarbon-dated horizons and the positions in each core of the disappearance of the foraminifer $G$. inflata for selected cores. 
tephrostratigraphy have already been outlined. The use of magnetic susceptibility data is also problematic, for susceptibility peaks may not always coincide with tephra layers, while fine ash layers often escape detection by this method (e.g. Abbott, 2005).

Correlations based on magnetic susceptibility data need to be corroborated by some other approach. Biostratigraphical marker events might be useful in this respect, though this approach assumes regional synchroneity in extinction and appearance of taxa, assumptions that may well be true but which need to be tested independently to avoid circular reasoning. There is an urgent need, therefore, for more reliable approaches to numerical dating and/or for determining age equivalence between records. Our key aim is to test the potential for tephrostratigraphy to meet these specific needs.

In order to succeed in this objective, the following limitations must be overcome. First, a more rigorous approach is required for classifying and comparing individual tephra layers. Ideally this should be based on the statistical comparison of geochemical data obtained from new tephra layers with some standardized ('type') geochemical data for each volcanic event. There are, however, no standardized protocols for carrying out such an exercise, or, for example, for comparing geochemical data obtained from distal ash layers with those obtained from proximal sites. Second, as noted above, the methods used to obtain geochemical data and for statistical treatment of the results vary markedly between different operators, and frequently rely on selected sub-sets of the data. Third, few core sequences have been examined systematically to ascertain the complete inventory of tephra layers preserved, which may include invisible distal ash layers. Finally, robust matching of tephra layers to key volcanic events of known age is a prerequisite for reliable tephrostratigraphy and tephrochronology. While some Holocene tephras, such as those corresponding to the Mercato and Inter-Plinian events, do appear to have diagnostic chemical signatures, others, such as those originating from Vesuvius, Agnano Monte Spina and Astroni, are proving to be less reliable. Some Holocene volcanic events appear to have been more complex than assumed hitherto, comprising several phases of activity spanning several centuries or more. 
Clearly it is not possible to address all of these limitations satisfactorily in one isolated experiment. This project was therefore confined to two key objectives: (a) the application of a more standardized and rigorous protocol for comparing geochemical signatures obtained from glass shards; and (b) the application of an alternative method for estimating the ages of individual tephras, one which avoids the marine reservoir problem. Central to this strategy was the extensive geochemical data-set generated for the tephras preserved in the Lago Grande di Monticchio lake sequence (Wulf et al., 2004). This not only provided a well constrained geochemical 'training set' against which the data obtained from the Adriatic records could be compared, but successful matching to the training set also enables the ages of some of the Adriatic tephras to be estimated in Monticchio varve years (MVY). It should be noted, however, that for logistical reasons we were not able to re-examine all of the core sequences depicted in Figure 7. Nine cores were selected for analysis, three of which were accessed through the Eurodelta project and the other six via complementary projects. Collectively they constitute a NNW-SSE transect through the Adriatic prodelta wedge (Figure 1), enabling the stratigraphic continuity of the Holocene tephra layers to be assessed.

\subsection{Experimental methods}

The following laboratory and analytical steps were adopted. First, all tephra extraction and preparation procedures followed the recently revised laboratory protocol of Blockley et al. (2005), which avoids the use of aggressive chemical reagents at all stages. Second, all chemical analyses were undertaken using microprobe WDS measurement to ensure that the results were directly comparable with the Lago Grande di Monticchio data-base. JEOL JXA8800R and Cameca SU-30 microprobes were utilised, both machines operating with a defocused $10 \mu \mathrm{m}$ beam size and a $10 \mathrm{n} \AA$ current. The beam count time for individual analyses was 20 seconds but this was reduced to 10 seconds for $\mathrm{Na}$ to avoid mobilization. Both machines were calibrated using modified standard blocks supplied by the instrument manufacturers, while NIST 612 and internally assayed 
'Lipari' obsidian were used as secondary standards to test comparability of results between the two microprobes. The dual probe strategy was devised in part to maximise the number of analyses in the study but also to test the reliability of the resulting geochemical data. Thirdly, all geochemical data were log-transformed prior to statistical treatment (logged to $\mathrm{Al}_{2} \mathrm{O}_{3}$ ) to correct for the unit sum problem and to ensure that the full statistical variance was taken into account. This approach limits the tendency for small ratio changes of elements present in low abundance to over-influence the results.

Finally, the Adriatic geochemical data were statistically compared with the Monticchio data-base using Discriminant Function Analysis (DFA - for explanation of this approach, see Aitchison, 1987; Pollard et al., in press). The Adriatic tephras fall into two groups, easily distinguished on stratigraphic criteria. The younger group is assigned to the mid Holocene or later because they all post-date the last occurrence of Globoratalia inflata (Figure 8). The other group comprises two older tephras detected in cores YD97-09 and PAL94-77-390 only. Two Monticchio training sets were therefore constructed for DFA. The first employed all data available for tephras dating to the interval 9678 to $1416 \mathrm{MVY}$ BP. The second spanned the mid Holocene to the Neapolitan Yellow Tuff, a widely dispersed regional marker dated to 14115-14106 MVY BP. The combined Monticchio data-set comprised 480 WDS measurements.

\subsection{Results}

DFA clearly discriminated twelve discrete data clusters (here termed the 'training groups') within the selected Monticchi data, which generally conform to the geochemical clusters found by Wulf et al. (2004) for this part of the record. Distinctive volcanic events in the Monticchio sequence are labelled TM- (see Table 2), numbered downwards from top, with TM-1 representing the youngest event. While some of the TM events are single, isolated tephra layers, a number comprise several closely spaced tephra layers. These may reflect pulsed eruptions from a single volcanic centre over a short interval of time, or pene-contemporaneous eruptions from more than one volcanic centre. TM-3 for example comprises three closely associated events, labeled TM-3a, TM-3b and TM-3c. This complexity apart, the key thing to note is that, with one exception, the individual 


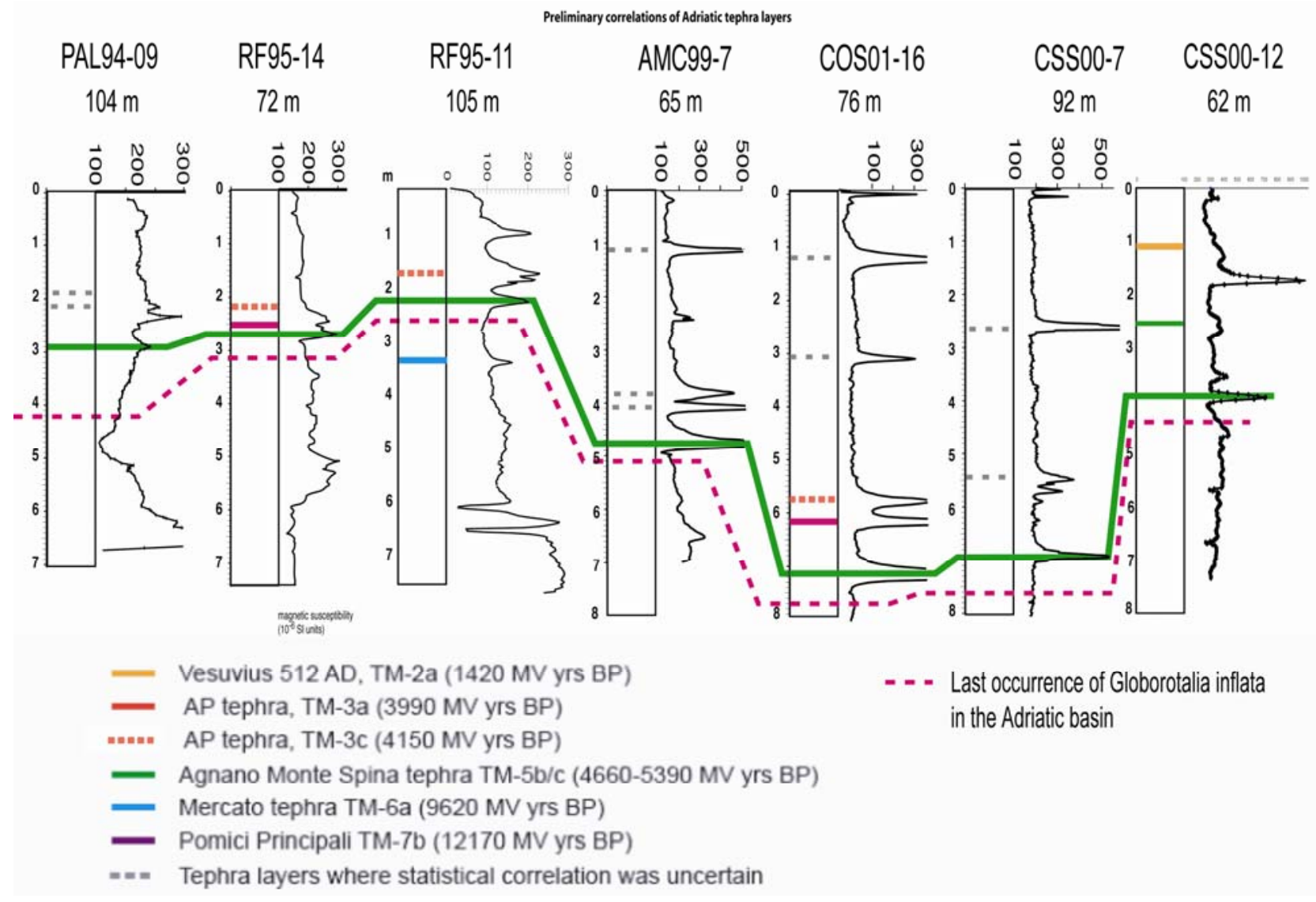

FIGURE 8: Positions of the tephras ascribed by Canonical Discriminant Analysis to dated tephras in the Monticchio training set.

tephra layers can be discriminated on the basis of their chemistry. This was tested by establishing how many of the individual WDS measurements obtained from a single tephra layer had been allocated to the corresponding training group. Results range from 71 to $100 \%$, with one exception, TM-5b (53\%). Indeed, the TM-5 group (a to c) are the least poorly resolved, largely because the number of WDS measurements available for this group is quite low. However, in no case were data assigned to a completely different TM group; mis-classification was always to another layer in the same TM group (e.g. $24 \%$ of the TM-5b results were allocated to TM-5a). Figure 9 shows a plot of the first three Canonical Discriminant Functions for the Holocene training set, accounting for $92.7 \%$ of the total variance. Overall the results are considered to provide an acceptable basis for discriminating between tephras. 


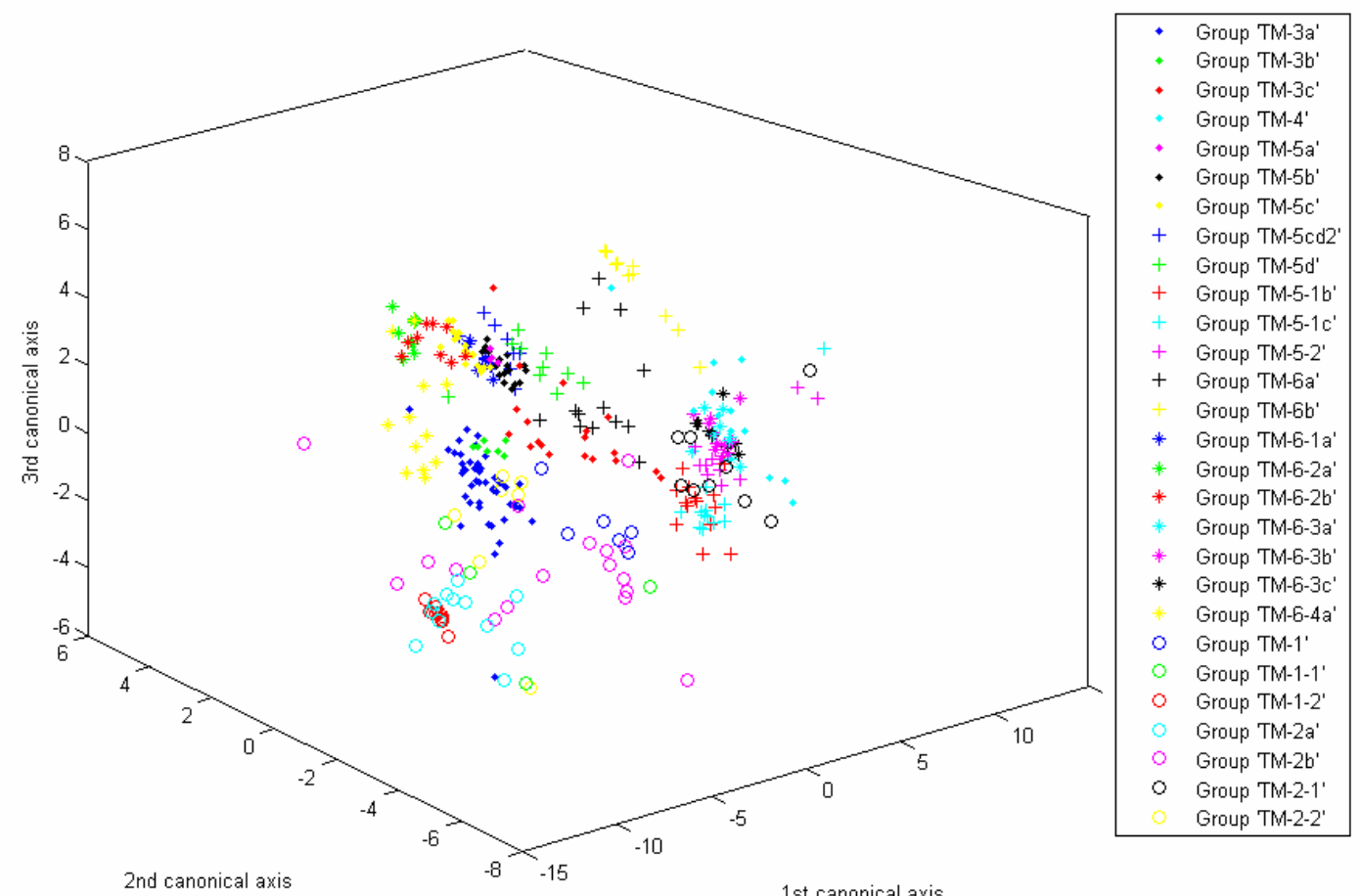

FIGURE 9: Plot of first three Discriminant Functions for the Monticchio Training Set (Holocene tephra groups only). For explanation see text, section 3.4.

\begin{tabular}{|c|c|c|c|c|c|c|c|c|c|c|c|c|c|c|c|c|}
\hline Sample & Phase & Group & TM-2a & $T M-2 b$ & TM-2-1 & TM-2-2 & TM-3a & TM-3b & TM-3c & TM-4 & AVER & TM-5a & TM-5b & TM-5c & TM-5cd2 & TM-5d \\
\hline RF95-11 316-321 & TM-6 & TM-6a & 0.0 & $\begin{array}{l}0.0 \\
\end{array}$ & 0.0 & 0.0 & \begin{tabular}{|l|}
0.0 \\
\end{tabular} & 0.0 & \begin{tabular}{|l|}
0.3 \\
\end{tabular} & 0.0 & 0.0 & 0.0 & $\begin{array}{r}0.0 \\
\end{array}$ & 0.0 & $\begin{array}{l}0.0 \\
\end{array}$ & $\begin{array}{l}0.0 \\
\end{array}$ \\
\hline RF95-11 205-210 & TM-5 & TM-5 b,c & 0.0 & 0.0 & 0.0 & 0.0 & 0.0 & 0.1 & 0.1 & 0.0 & 0.0 & 7.8 & 34.5 & 8.3 & 8.2 & 16.5 \\
\hline RF95-11 154159 & TM-3 & TM-3a & 0.0 & 0.3 & 0.0 & 0.2 & 66.3 & 6.6 & 17.9 & 0.0 & 0.0 & 0.0 & 0.0 & 0.0 & 0.0 & 0.0 \\
\hline RF94-14 240 242 & TM-3 & TM-3a & 0.0 & 0.3 & 0.0 & 0.2 & 66.3 & 6.6 & 17.9 & 0.0 & 0.0 & 0.0 & 0.0 & 0.0 & 0.0 & 0.0 \\
\hline RF95-14 270 272 & TM-5 & TM -5 b,c & 0.0 & 0.0 & 0.0 & 0.0 & 0.0 & 0.0 & 0.0 & 0.0 & 0.0 & 0.1 & 21.5 & 69.8 & 0.3 & 1.0 \\
\hline Rf 95-14 258260 & TM-3 & TM-3c,a & 0.0 & 0.0 & 0.0 & 0.1 & 38.8 & 6.1 & 55.4 & 0.0 & 0.0 & 0.0 & 0.0 & 0.0 & 0.0 & 0.0 \\
\hline COSO1-16 734 & TM-5 & TM-5c & 0.0 & 0.0 & 0.0 & 0.0 & 0.0 & 0.0 & 0.0 & 0.0 & 0.0 & 0.0 & 0.0 & 100.0 & 0.0 & 0.0 \\
\hline CSS00-12 172 Basic & TM-2 & TM-2a & 99.7 & 0.3 & 0.0 & 0.0 & 0.0 & 0.0 & 0.0 & 0.0 & 0.0 & 0.0 & 0.0 & 0.0 & 0.0 & 0.0 \\
\hline PAL94-09 291.5-293. & TM-5 & TM-5c & 0.0 & 0.0 & 0.0 & 0.0 & 0.0 & 0.0 & 0.0 & 0.0 & 0.0 & 0.0 & 0.2 & 97.9 & 0.0 & 0.0 \\
\hline CSS012-393.5 & TM-5 & TM-5c & 0.0 & 0.0 & 0.0 & 0.0 & 0.0 & 0.0 & 0.0 & 0.0 & 0.0 & 0.4 & 25.4 & 71.6 & 1.0 & 0.9 \\
\hline CSS00-07 690-693 & TM-5 & TM-5b,c & 0.0 & 0.0 & 0.0 & 0.0 & 0.0 & 0.0 & 0.0 & 0.0 & 0.0 & 0.5 & 54.8 & 14.4 & 2.1 & 4.1 \\
\hline AMC-997 480-484 & TM-5 & TM-5c & 0.0 & 0.0 & 0.0 & 0.0 & 0.0 & 0.0 & 0.0 & 0.0 & 0.0 & 0.4 & 25.9 & 69.6 & 0.8 & 0.7 \\
\hline CSS01-16 622 & TM-3 & $T M-3 c$ & 0.0 & 0.0 & 0.0 & 0.0 & 0.0 & 0.0 & 98.2 & 0.0 & 0.0 & 0.0 & 0.0 & 0.0 & 0.0 & 0.0 \\
\hline cos01-16 586 & TM-3 & TM-3a & 0.0 & 6.8 & 0.0 & 0.5 & 70.4 & 2.6 & 5.1 & 0.0 & 0.0 & 0.0 & 0.0 & 0.0 & 0.0 & 0.0 \\
\hline \\
\hline Sample & Phase & Group & TM-3a & $T M-3 b$ & TM-3c & TM-4 & TM-5a & TM-5b & TM-5c & TM-5cd2 & TM-5d & TM-5-1b & TM-5-1C & \begin{tabular}{|l|} 
TM-5-2 \\
\end{tabular} & TM-6a & TM-6b \\
\hline YD-97-9 & $T M-7$ & TM-7b & 0.0 & $\begin{array}{r}0.0 \\
\end{array}$ & 0.0 & 0.0 & \begin{tabular}{|l|}
0.0 \\
\end{tabular} & $\begin{array}{r}0.0 \\
\end{array}$ & \begin{tabular}{|l|}
0.0 \\
\end{tabular} & $\begin{array}{r}0.0 \\
\end{array}$ & 0.0 & $\begin{array}{r}0.0 \\
\end{array}$ & $\begin{array}{r}0.0 \\
\end{array}$ & $\begin{array}{l}0.0 \\
\end{array}$ & $\begin{array}{r}0.0 \\
\end{array}$ & $\begin{array}{r}0.0 \\
\end{array}$ \\
\hline \multirow[t]{4}{*}{ PAL 94-77-390 } & TM-7 & $T M-7 b$ & 0.2 & $\begin{array}{l}0.0 \\
\end{array}$ & 0.0 & $\begin{array}{l}0.0 \\
\end{array}$ & 0.1 & $\begin{array}{l}0.1 \\
\end{array}$ & \begin{tabular}{|l|}
0.0 \\
\end{tabular} & $\begin{array}{l}0.0 \\
\end{array}$ & $\begin{array}{l}0.0 \\
\end{array}$ & 0.0 & $\begin{array}{l}0.0 \\
\end{array}$ & 0.0 & 0.0 & 0.0 \\
\hline & & & 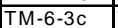 & TM-6-4a & TM-6-4b & TM-6-4c & TM-6-5a & TM-6-5b & TM-6-5c & TM-7a & TM-7b & TM-7-1a & \begin{tabular}{|l|}
$T M-7-2$ \\
\end{tabular} & TM-7-3 & \begin{tabular}{|l|} 
TM-8 \\
\end{tabular} & TM-9 \\
\hline & & & 0 & $\begin{array}{l}0.0031 \\
\end{array}$ & 0.0952 & \begin{tabular}{|l|}
0.8273 \\
\end{tabular} & \begin{tabular}{|l|}
0.3722 \\
\end{tabular} & \begin{tabular}{|l|}
0.6993 \\
\end{tabular} & \begin{tabular}{|l|}
0.7257 \\
\end{tabular} & $\begin{array}{l}0.0001 \\
\end{array}$ & \begin{tabular}{|l|}
53.5706 \\
\end{tabular} & \begin{tabular}{|l|}
0.114 \\
\end{tabular} & $\begin{array}{l}0.0916 \\
\end{array}$ & $\begin{array}{l}0.0004 \\
\end{array}$ & \begin{tabular}{|l|}
0.4593 \\
\end{tabular} & 0 \\
\hline & & & 0 & 0.0618 & 0.55905 & 1.9981 & 0.79465 & 0.758 & 1.30225 & 1.1368 & 85.1504 & 0.6633 & 0.3998 & 0.00955 & 1.92025 & 0 \\
\hline
\end{tabular}

TABLE 2: $\quad$ Summary of most likely allocations (median values) of Adriatic datagroups to the Monticchio training groups based on Canonical Discriminant Analysis scores. (For further explanation see text sections 3.3 and 3.4) This shows a representative selection of computed scores only, based on more extensive tables of results, an example of which is provided in Table 3. 
The distinct clusters within the Monticchio training sets represent the Pomici Principali (Monticchio group TM-7), Agnano Monte Spina (TM-5 group, except 5b and 5c), Astroni (TM-5b and TM-5c) and Vesuvian Ap tephras (TM-3). There is wider scatter, and overlap between, the results for the Mercato (TM-6) and Avellino (TM-4) tephras. The results suggest that this approach is able to discriminate well between some of the phases of the Vesuvian Ap activity, while it may possible in the future, with additional data, to distinguish between different phases of AMS and Astroni activity. Distinction between Mercato and Avellino tephras is likely to remain problematic, but will be clear on stratigraphical grounds if both are found in the same core, and/or if the AMS/Astroni tephras are also present in the same sequence. Of course, the full succession will also be resolvable in a marine sequence if, as at Monticchio, all of the events are preserved in correct stratigraphic order.

Distinct peaks in glass shard concentration were detected in 20 horizons within the Adriatic sediments examined, distributed between the nine core sequences as indicated in Figure 8. Several shards were extracted from each of the tephra layers from which $>800$ WDS measurements were obtained, though analytical totals were low $(<94 \%)$ in some cases. Totals can be low because of the very small size of the shards, the presence of mineral inclusions, or water content. It is particularly difficult to focus the microprobe beam on to flat, uncontaminated surfaces when the shards are not only very small, but are also highly vesicular and contain mineral inclusions. The WDS values with very low analytical totals were therefore removed, leaving a total of 639 data-points with analytical totals $>94 \%$. DFA was conducted to compare these data with the 12 discrete clusters that characterise the Monticchio training sets.

Two allocation methods were tested. First, the Mahalanobis Distance of all samples to the most likely Monticchio group mean was calculated, giving a crude indication of the reliability of the allocation. Second, because not all of the log-ratio data were normally distributed, a logistic regression allocation was also applied (Aitchison, 1987; Nathan and Pollard, in prep). These procedures generate extensive percentage allocation tables, which 
estimate the probability of a match between individual data points and a test group (in this instance each training group). An example is provided in Table 3, which consists of an indicative sub-set of the data only, to illustrate how the summary data (Table 2) were derived. A conclusive match to the Monticchio training set was only accepted if either the percentage allocation to a Monticchio training group is high (i.e. there is little probability that the data match more successfully to any other sub-group), or the samples are most frequently allocated to more than one sub-group within the same Monticchio TM horizon. The overall results of this exercise led to the tephra identifications and correlations shown in Figure 8. Confident allocations are possible for 15 of the 20 tephra layers studied. Problems were encountered with the remaining five samples because of the difficulties of obtaining reliable microprobe data from very small, highly vesicular glass shards.

The Adriatic data are reasonably well clustered into groups, the majority of which match the clusters in the training set (Table 2; Figure 8). In some instances the match suggested by DFA is unequivocal, such as the allocations of the three tephras in core RF95-11 to the TM-6a (Mercato), TM-5c (Astroni) and TM-3 (Vesuvian AP events) respectively, and of single tephra horizons in cores PAL94-77 and YD 97-09 to the Pomici Principali event (Figure 8). Table 3 provides the example of the full set of canonical discriminant results derived for the tephra horizon located in core RF95-11 between depths 316-321 cm. It can be seen that the highest canonical scores are nearly always allocated to Tephra type TM-6a (Mercato tephra). In other instances the DFA acceptance scores are low (Table 2), and attribution therefore less clear, usually because the number of microprobe measurements available is too low for confident statistical comparison.

The results of the experiment are encouraging, demonstrating that fine (distal) ash layers are preserved within prodelta sediment sequences in correct stratigraphic order, a number of which can be matched to type material. 16 out of the 20 layers examined could be assigned to one of two or, at most, three phases of activity that occurred within a limited time period, while others could be assigned to single volcanic events. It should be noted, 


\begin{tabular}{|c|c|c|c|c|c|c|c|c|c|c|c|c|c|c|c|c|c|c|c|c|}
\hline posterior & & & & & & & & & & & & & & & & & & & & \\
\hline \begin{tabular}{l|l|} 
& Group \\
\end{tabular} & TM-2a & TM-2b & TM-2-1 & TM-2-2 & TM-3a & TM-3b & TM-3C & TM-4 & AVER & TM-5a & TM-5b & TM-5C & TM-5cd2 & TM-5d & TM-5-1b & TM-5-1c & TM-5-2 & & TM-6a & TM-6b \\
\hline 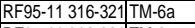 & 0 & 0 & \begin{tabular}{|l|}
0.0003 \\
\end{tabular} & 0 & 0 & 0 & 0.0101 & 0 & 0.0002 & 0 & 0 & 0 & $\begin{array}{r}0 \\
\end{array}$ & 0 & 0 & 0 & & 0 & 99.989 & 0.0004 \\
\hline \begin{tabular}{|l|l|} 
RF95-11 316-321 TM-6a \\
\end{tabular} & 0 & 0 & 0.0006 & 0 & 0 & 0 & 0.0013 & 0.0001 & 0.0001 & 0 & 0 & 0 & 0 & 0 & 0 & 0 & & 0 & 99.9975 & 0.0004 \\
\hline \begin{tabular}{|l|l|l|} 
RF95-11 316-321 TM-6a \\
\end{tabular} & 0 & 0 & 0.1417 & 0 & 0 & 0.0014 & 11.4477 & 0 & 0.0011 & 0 & 0 & 0 & 0 & 0.0053 & 0 & 0 & & 0 & 88.4027 & \\
\hline \begin{tabular}{|l|l|} 
RF95-11 316-321 TM-6a \\
\end{tabular} & 0 & 0 & 0.0025 & 0 & 0 & 0 & 0.0582 & 0.0007 & 0.0001 & 0 & 0 & 0 & 0 & 0 & 0 & 0 & & 0 & 99.936 & 0.0026 \\
\hline \begin{tabular}{|l|l|} 
RF95-11 316-321 TM-6a \\
\end{tabular} & 0 & 0 & 0.5423 & 0 & 0 & 0.008 & 38.1176 & 0 & 0.0126 & 0 & 0 & 0 & 0 & 0.0017 & 0 & 0 & & 0 & 61.3177 & 0.0001 \\
\hline \begin{tabular}{|l|l|} 
RF95-11 316-321 TM-6a \\
\end{tabular} & 0 & 0 & 0.0005 & 0 & 0 & 0 & 0.0035 & 0 & 0.0002 & 0 & 0 & 0 & 0 & 0 & 0 & 0 & & 0 & 99.9941 & 0.0017 \\
\hline \begin{tabular}{|l|l|l|} 
RF95-11 316-321 & TM-6a \\
\end{tabular} & 0 & 0 & 0.0002 & 0 & 0 & 0 & 0.007 & 0.0001 & 0.0001 & 0 & 0 & 0 & 0 & 0 & 0 & 0 & & 0 & 99.9888 & 0.0038 \\
\hline \begin{tabular}{|l|l|l|} 
RF95-11 316-321 & TM-6a \\
\end{tabular} & 0 & 0 & 0.028 & 0 & 0 & 0.0017 & 5.04 & 0 & 0.0022 & 0 & 0 & 0 & 0 & 0.0011 & 0 & 0 & & 0 & 94.9269 & \\
\hline \begin{tabular}{|l|l|} 
RF95-11 316-321 & TM-6a \\
\end{tabular} & 0 & 0 & 0.1575 & 0 & 0 & 0 & 0.0959 & 0 & 0.0307 & 0 & 0 & 0 & 0 & 0.0001 & 0 & 0 & & 0 & 99.7154 & 0.0003 \\
\hline \begin{tabular}{|l|l|l|} 
RF95-11 316-321 & TM-5b \\
\end{tabular} & 0 & 0 & 0.0011 & 0 & 0 & 0 & 0.0002 & 0 & & 0.0401 & 83.3534 & 11.0537 & 0.7924 & 4.759 & 0 & 0 & 0.000 & & 0.0001 & \\
\hline \begin{tabular}{|l|l|l|} 
RF95-11 316-321 \\
\end{tabular} & 0 & 0 & 0.0122 & 0 & 0 & 0 & 0.0436 & 0.0004 & 0.0473 & 0 & 0 & 0 & 0 & 0 & 0 & 0 & & 0 & 99.8741 & 0.0223 \\
\hline \begin{tabular}{|l|l|l|} 
RF95-11 316-321 & TM-2-1 \\
\end{tabular} & 0 & 0 & 51.3557 & 0 & 0 & 0 & 0.1892 & 0 & 0.185 & 0 & 0 & 0 & 0 & 0.1329 & 0 & 0 & & 0 & 48.1372 & \\
\hline \begin{tabular}{|l|l|l|} 
RF95-11 316-321 & TM-6a \\
\end{tabular} & 0 & 0 & 26.394 & 0 & 0 & 0.0001 & 0.3199 & 0 & 0.2396 & 0 & 0 & 0 & 0 & 0.0664 & 0 & 0 & & 0 & 72.9801 & \\
\hline RF95-11 316-321 TM-6a & 0 & 0 & 0.0183 & 0 & 0 & 0 & 0.2062 & 0 & 0.0053 & 0 & 0 & 0 & 0 & 0.0001 & 0 & 0 & & 0 & 99.7696 & 0.0004 \\
\hline \begin{tabular}{|l|l|l|} 
RF95-11 316-321 & TM-6a \\
\end{tabular} & 0 & 0 & & 0 & 0 & 0 & 0.0006 & 0 & 0 & 0 & 0 & 0 & 0 & 0 & 0 & 0 & & 0 & $\begin{array}{l}99.9994 \\
\end{array}$ & \\
\hline \begin{tabular}{|l|l|} 
RF95-11 316-321 TM-6a \\
\end{tabular} & 0 & 0 & 0.0006 & 0 & 0 & 0 & 0.0079 & 0.0016 & 0.012 & 0 & 0 & 0 & 0 & 0 & 0 & 0 & & 0 & 99.9328 & 0.0451 \\
\hline \begin{tabular}{|l|l|l|} 
RF95-11 316-321 & TM-6a \\
\end{tabular} & 0 & 0 & 0 & 0 & 0 & 0 & & 5.6419 & 0 & 0 & 0 & 0 & 0 & 0 & 0 & 0 & & 0 & 59.7786 & 34.5795 \\
\hline \begin{tabular}{|l|l|l|} 
RF95-11 316-321 & TM-6a \\
\end{tabular} & 0 & 0 & 0.0003 & 0 & 0 & 0 & 0.0229 & 0.0031 & 0 & 0 & 0 & 0 & 0 & 0 & 0 & 0 & & 0 & 99.9551 & 0.0186 \\
\hline \begin{tabular}{|l|l|} 
RF95-11 316-321 TM-6a \\
\end{tabular} & 0 & 0 & 0.2402 & 0 & 0 & 0 & 30.2791 & 0.0051 & 0 & 0 & 0 & 0 & 0 & 0.0005 & 0 & 0 & & 0 & 69.4738 & 0.0012 \\
\hline \begin{tabular}{|l|l|} 
RF95-11 316-321 TM-6a \\
\end{tabular} & 0 & 0 & 0.0561 & 0 & 0 & 0 & 0.0263 & 0.0004 & 0 & 0 & 0 & 0 & 0 & 0 & 0 & 0 & & 0 & 99.9165 & 0.0007 \\
\hline \begin{tabular}{|l|l|l|} 
RF95-11 316-321 & TM-6a \\
\end{tabular} & 0 & 0 & 0.2837 & 0 & 0 & 0 & 0.4065 & 0.0003 & 0.0045 & 0 & 0 & 0 & 0 & 0 & 0 & 0 & & 0 & 99.3042 & 0.0007 \\
\hline \begin{tabular}{|l|l|l|} 
RF95-11 316-321 TM-6a \\
\end{tabular} & 0 & 0 & 0.5827 & 0 & 0 & 0.0004 & 30.0959 & 0.0018 & 0.0193 & 0 & 0 & 0 & 0 & 0.0006 & 0 & 0 & & 0 & 69.2434 & 0.0559 \\
\hline \begin{tabular}{|l|l|} 
RF95-11 316-321 TM-6a \\
\end{tabular} & 0 & 0 & 0.0023 & 0 & 0 & 0 & 0.0096 & 0 & 0.0004 & 0 & 0 & 0 & 0 & 0 & 0 & 0 & & 0 & 99.9876 & \\
\hline \begin{tabular}{|l|l|} 
RF95-11 316-321 TM-6a \\
\end{tabular} & 0 & 0 & 0.2317 & 0 & 0 & 0.0001 & 3.003 & 0 & 0.0099 & 0 & 0 & 0 & 0 & 0.0022 & 0 & 0 & & 0 & 96.7529 & 0.0001 \\
\hline \begin{tabular}{|l|l|} 
RF95-11 316-321 TM-6a \\
\end{tabular} & 0 & 0 & 0.212 & 0 & 0 & 0.0002 & 7.722 & 0.0295 & 0.0301 & 0 & 0 & 0 & 0 & 0.0001 & 0 & 0 & & 0 & 91.5442 & 0.4619 \\
\hline \begin{tabular}{|l|l|} 
RF95-11 316-321 TM-6a \\
\end{tabular} & 0 & 0 & 0.0049 & $\overline{0}$ & 0 & 0 & 0.1574 & 0.0051 & 0 & 0 & 0 & 0 & 0 & 0 & 0 & 0 & & 0 & 99.8275 & 0.0051 \\
\hline \begin{tabular}{|l|l|} 
RF95-11 316-321 & TM-6a \\
\end{tabular} & 0 & 0 & & 0 & 0 & 0 & & 1.2924 & 0 & 0 & 0 & 0 & 0 & 0 & 0 & 0 & & 0 & 97.5251 & 1.1825 \\
\hline \begin{tabular}{|l|l|} 
RF95-11 316-321 TM-6a \\
\end{tabular} & 0 & 0 & 0.0018 & 0 & 0 & 0 & 0.1691 & 0.1654 & 0 & 0 & 0 & 0 & 0 & 0 & 0 & 0 & & 0 & $\begin{array}{l}99.6493 \\
\end{array}$ & 0.0144 \\
\hline RF95-11 316-321 TM-6a & 0 & 0 & 0.0626 & 0 & 0 & 0.0001 & 1.3207 & 0.0543 & 0.0086 & 0 & 0 & 0 & 0 & 0 & 0 & 0 & & 0 & 98.394 & 0.1596 \\
\hline \begin{tabular}{|l|l|} 
RF95-11 316-321 TM-6a \\
\end{tabular} & 0 & 0 & 0.2782 & 0 & 0 & 0.0041 & 16.8287 & 0 & 0.0204 & 0 & 0 & 0 & 0 & 0.0032 & 0 & 0 & & 0 & 82.8654 & \\
\hline RF95-11 316-321 TM-6a & 0 & 0 & 0.0046 & 0 & 0 & 0 & 0.4737 & 0.0081 & 0.0034 & 0 & 0 & 0 & 0 & 0 & 0 & 0 & & 0 & 99.4101 & 0.1002 \\
\hline \begin{tabular}{|l|l|} 
RF95-11 316-321 TM-6a \\
\end{tabular} & 0 & 0 & 0.1729 & 0 & 0 & 0 & 24.6015 & 0.0481 & 0 & 0 & 0 & 0 & 0 & 0.0001 & 0 & 0 & & 0 & 75.1758 & 0.0016 \\
\hline \begin{tabular}{|l|l|} 
RF95-11 316-321 TM-6a \\
\end{tabular} & 0 & 0 & 0.001 & 0 & 0 & 0 & 0.0398 & 0.0006 & 0.0083 & 0 & 0 & 0 & 0 & 0 & 0 & 0 & & 0 & 99.917 & 0.0333 \\
\hline \begin{tabular}{|l|l|} 
RF95-11 316-321 TM-6a \\
\end{tabular} & 0 & 0 & 1.8777 & 0 & 0 & 0.0004 & 38.5257 & 0.0158 & 0.0007 & 0 & 0 & 0 & 0 & 0.0006 & 0 & 0 & & 0 & 59.5754 & 0.0037 \\
\hline \begin{tabular}{|l|l|} 
RF95-11 316-321 TM-6a \\
\end{tabular} & 0 & 0 & 0.1861 & 0 & 0 & 0.0003 & 7.8749 & 0.0255 & 0.0055 & 0 & 0 & 0 & 0 & 0.0001 & 0 & & & 0 & 91.8459 & 0.0617 \\
\hline \begin{tabular}{|l|l|} 
RF95-11 316-321 & TM-3c \\
\end{tabular} & 0 & 0 & 0.0084 & 0.0001 & 0.0402 & 0.6622 & 98.8594 & 0 & 0.0001 & 0 & 0 & 0 & 0 & 0.0002 & 0 & 0 & & 0 & 0.4293 & \\
\hline \begin{tabular}{|l|l|} 
RF95-11 316-321 & TM-6a \\
\end{tabular} & 0 & 0 & 0.5602 & 0 & 0 & 0.0019 & 14.7277 & 0.0048 & 0.02 & 0 & 0 & 0 & 0 & 0.0003 & 0 & 0 & & 0 & 84.6805 & 0.0046 \\
\hline RF95-11 316-321 TM-6a & 0 & 0 & 0.0111 & 0 & 0 & 0.0001 & 2.2999 & 0.0088 & 0.0009 & 0 & 0 & 0 & 0 & 0.0001 & 0 & 0 & & 0 & 97.6546 & 0.0245 \\
\hline \begin{tabular}{|l|l|} 
RF95-11 316-321 TM-6a \\
\end{tabular} & 0 & 0 & \begin{tabular}{ll|}
0.1586 \\
\end{tabular} & 0 & 0 & 0.0001 & 24.7867 & 0.2365 & 0.0006 & 0 & 0 & 0 & 0 & 0.0003 & 0 & 0 & & 0 & 74.6739 & 0.1432 \\
\hline \begin{tabular}{|l|l|} 
RF95-11 316-321 TM-6a \\
\end{tabular} & 0 & 0 & 0.0972 & 0 & 0 & 0.0003 & 23.1269 & 0.0024 & 0.0002 & 0 & 0 & 0 & 0 & 0.0005 & 0 & 0 & & 0 & 76.7721 & 0.0005 \\
\hline RF95-11 316-321 TM-6a & 0 & 0 & 0.0023 & 0 & 0 & 0 & 0.0378 & 0.0001 & 0 & 0 & 0 & 0 & 0 & 0 & 0 & 0 & & 0 & 99.9589 & 0.0007 \\
\hline \begin{tabular}{|l|l|} 
RF95-11 316-321 TM-6a \\
\end{tabular} & 0 & 0 & 0.0006 & 0 & 0 & 0 & 0.7491 & 0.0001 & 0 & 0 & 0 & 0 & 0 & 0.0001 & 0 & 0 & & 0 & 99.2479 & 0.0021 \\
\hline
\end{tabular}

TABLE 3: The full allocation output for Adriatic group RF95-11, 316-321 cm. This shows the most likely allocation of each WDS array obtained from each shard analysed in this group, and which led to the summary allocation to Monticchio group TM6-a (Mercato tephra) in Table 2.

however, that this experiment was limited to the screening of selected segments in each core sequence - those showing high magnetic susceptibility peaks. The only way to establish the full tephrostratigraphic record preserved in each sediment sequence is to undertake a systematic investigation of each full succession. This approach is likely to reveal additional tephra layers not represented in Figure 8, which may resolve some of the problematic cases. Furthermore, we believe that clearer discrimination between the tephras, and even between the different phases of the AMS, Astroni and Vesuvian suites, will become possible as the data-bank of chemical determinations grows, but only if the measurements are undertaken with sufficient rigour. 
A further outcome of the experiment is that Monticchio varve ages can be assigned to those Adriatic tephras that can be confidently matched to the Monticchio tephra succession (bottom of Figure 8). Note that the varve ages shown do not include the uncertainties in the varve chronology (Brandt et al., 1999), while there are also uncertainties in determining which precise horizon within a tephra layer coincides with the time of volcanic explosion. Complicating factors might include irregular delivery of tephra material to the site, changes in the manner and rate of sedimentation during tephra deposition and possible downward transport of shards due to biogenic mixing. Nevertheless the results illustrate the potential this approach offers for testing and improving age models obtained from marine sequences based on radiocarbon dating. Indeed, if tephrostratigraphical research can be applied more routinely, and the ages of the tephras more confidently established, then tephrochronology could, in theory, replace radiocarbon dating as the more efficient, standard procedure for dating late Quaternary sequences in areas that fall within the footprints of key ashfalls.

\section{Conclusions}

The key conclusions to emerge from the arguments presented in this paper are as follows.

1. Radiocarbon-based age models for Holocene stratigraphical records cannot normally deliver better than centennial precision, unless a minimum of 24 radiocarbon dates is available to support the models. Age models for preHolocene periods are even less precise, with uncertainties commonly millennial in scale, mainly because of the limitations of currently-available calibration models. Radiocarbon dating of marine records is particularly problematic because of the pervasive and, at present, poorly constrained marine reservoir effects.

2. Independent methods are therefore needed to constrain and correct radiocarbonbased age models and to test correlations based upon them. Tephrostratigraphy appears to provide the best opportunity for achieving this, as far as the Adriatic, and possibly other parts of the central Mediterranean, are concerned.

3. If tephrostratigraphy is to fulfil this role, methods of tephra extraction, geochemical analysis and statistical classification need to be better standardised and more rigorous than has generally been the case hitherto. The current practice 
of chemical classification based on biplots or triplots of selected element ratios does not capture the true variance between data-sets, and may lead to spurious identifications and correlations. The use of methods that examine the full geochemical data-suites available, such as Canonical Discriminant Analysis, coupled with (i) an increase in the size of the geochemical data-sets generated for each tephra under study and (ii) log-ratio transformation of the data, should provide more stringent tests of the degree of discrimination or similarity between tephras.

4. Regional tephrostratigraphical type sequences containing tephra layers that are preserved in unequivocal stratigraphic succession, and within which the chemical signatures and ages of individual tephras can be established reliably, are pivotal for generating standards against which less complete or more stratigraphically complex sequences can be compared. The Lago Grande di Monticchio record is currently the best candidate to fulfill this role for the central Mediterranean region.

In due course, the stratigraphical succession of tephras preserved in the late Quaternary sediments of the Mediterranean will become more fully understood, and their ages and chemical characteristics better defined. This will undoubtedly increase their value in providing a stratigraphic ‘template’ of isochronous volcanic events. Stratigraphic complexities (resedimentation, hiatuses, bioturbation, etc.) may serve to distort the records locally, but our experiences of tephrostratigraphical records in the Adriatic so far, together with the data published by Siani et al. (2004), indicate the preservation of a sequential order of tephra layers in several deep and shallow basins. Hence, volcanic event stratigraphy appears to have wide application, and, at least for sediments dating to the last 50,000 years (the limits of conventional radiocarbon dating), provides a well constrained, independent basis for testing radiocarbon-based age models. Its wider adoption should bring greater clarity to reconstructions of the rate and pattern of sedimentary accretion in the Adriatic. 


\section{Acknowledgements}

We gratefully acknowledge the following two main sources of funding support for the work reported in this paper:

1 EURODELTA Concerted Action, a project dedicated to European Co-ordination on Mediterranean Prodeltas funded within the European Union's $5^{\text {th }}$ Framework research programme entitled Energy, Environment and Sustainable Development (Contract No. EVK3-CT-2001-20001).

2 EUROSTRATAFORM, a scientific research programme exploring the fate of sediment particles from their source in rivers through to their deposition on shallow deltas, the continental shelf and deep sea basins. (Contract No. EVK3CT-2002-00079)

Our thanks are also extended to G. Gasporotto for advice on the analysis of tephra samples.

\section{$\underline{\text { References }}$}

Abbott, P. M., 2005. Towards a tephrochronology for a southern Adriatic deep marine sequence. MSc Thesis, University of London, unpublished.

Aitchison, J., 1987. The Statistical Analysis of Compositional Data. Blackburn Press, Caldwell, NJ (reprinted 2003).

Alley, R.B., Clark, P.U., 1999. The deglaciation of the Northern Hemisphere: a global perspective. Annual Review of Earth and Planetary Sciences 27, 149-182.

Alley, R.B., Meese, D.A., Shuman, C.A., Gow, A.J., Taylor, K.C., Grootes, P.M., White, J.W.C., Ram, M., Waddington, E.D., Mayewski, P.A., Zielinski, G.A., 1993. Abrupt increase in Greenland snow accumulation at the end of the Younger Dryas. Nature 362, 527-529.

Ascough, P., Cook, G. \& Dugmore, A., 2005. Methodological approaches to determining the marine radiocarbon reservoir effect. Progress in Physical Geography 29, 532-547. 
Asioli, A., 1996. High-resolution Foraminifera biostratigraphy in the Central Adriatic basin during the Last Deglaciation: a contribution to the PALICLAS project. Memorie del'Istituto Italiano di Idrobiologia 55, pp. 197-218.

Asioli, A., Trincardi, F., Lowe, J.J., Oldfield, F., 1999. Short-term climate changes during the Last Glacial-Holocene transition: comparison between Mediterranean records and the GRIP event stratigraphy. Journal of Quaternary Science 14, 373-381.

Austin, W.E.N., Bard, E., Hunt, J.B., Kroon, D., Peacock, J.D., 1995. The ${ }^{14} \mathrm{C}$ age of the Icelandic Vedde Ash: implications for Younger Dryas marine reservoir age corrections. Radiocarbon 37, 53-62.

Bard, E., Arnold, M., Mangerud, J., Paterne, M., Labeyrie, L., Duprat, J., Melieres, MA., Sonstegaard, E., Duplessy, J-C., 1994. The North Atlantic atmosphere-sea surface ${ }^{14} \mathrm{C}$ gradient during the Younger Dryas climatic event. Earth and Planetary Science Letters 126, 275-287.

Bard, E., Arnold, M., Hamelin, B., Tisnerat-Laborde, N., Cabioch, G., 1998. Radiocarbon calibration by means of mass spectrometric ${ }^{230} \mathrm{Th} /{ }^{234} \mathrm{U}$ and ${ }^{14} \mathrm{C}$ ages of corals: an updated database including samples from Barbados, Mururoa and Tahiti. Radiocarbon 40, 1085-1092.

Bard, E., Rostek, F., Turon, J.L., Gendreau, S., 2000. Hydrological impact of Heinrich events in the subtropical northeast Atlantic. Science 289, 1321-1324.

Bard, E., Rostek, F., Ménot-Combes, G., 2004a. Radiocarbon calibration beyond 20,000 ${ }^{14} \mathrm{C}$ yr B.P. by means of planktonic foraminifera of the Iberian margin. Quaternary Research 61, 204-214.

Bard, E., Rostek, F., Ménot-Combes, G., 2004b. A better radiocarbon clock. Science 303, 178-179.

Beck, J.W., Richards, D.A., Edwards, R.L., Silverman, B.W., Smart, P.L., Donahue, D.J., Hererra Osterfeld, S., Burr, G.S., Calsoyas, L., Jull, A.J., Biddulph, D., 2001. Extremely large variations of atmospheric ${ }^{14} \mathrm{C}$ concentration during the last glacial period. Science 292, 2453-2458. 
Beer, J., Muscheler, R., Wagner, G., Laj, C., Kissel, C., Kubik, P.W., Synal, H.A., 2002. Cosmogenic nuclides during Isotope Stages 2 and 3. Quaternary Science Reviews 21, 1129-1139.

Bennett, K.D., 1994. Confidence intervals for age estimates and deposition times in lateQuaternary sediment sequences. The Holocene 4, 337-348.

Blaauw, M., Van Geel, B., Mauquoy, D., van der Plicht, J., 2004. Carbon-14 wigglematch dating of peat deposits: advantages and limitations. Journal of Quaternary Science 19, 177-181.

Blockley, S.P.E., Donahue, R.E., Pollard, A.M., Ward, K.R., 2003. Establishing Lateglacial and Holocene marine reservoir radiocarbon offsets in the northern North Atlantic: the potential for improving the chronology of Arctic archaeology. Physics in Canada 59 263-268.

Blockley, S., Lowe, J.J., Walker, M.J.C., Asioli, A., Trincardi, F., Coope, G.R., Donahue, R.E., Pollard, A.M., 2004. Bayesian analysis of radiocarbon chronologies: examples from the European Late-glacial. Journal of Quaternary Science 19, 159175.

Blockley, S.P.E., Pyne-O’Donnell, S., Lowe, J.J., Matthews, I.P., Stone, A., Pollard, A.M., Turney, C.S.M., Molyneux, E.G., 2005. A new and less destructive laboratory procedure for the physical separation of distal glass tephra shards from sediments. Quaternary Science Reviews 24, 1952-1960.

Bowman, S., 1990. Radiocarbon Dating. British Museum, London.

Brandt, U., Nowaczyk, N.R., Ramrath, A., Brauer, A., Mingram, J.,Wulf, S., Negendank, J.F.W., 1999. Palaeomagnetism of Holocene and Late Pleistocene sediments from Lago di Mezzano and Lago Grande di Monticchio (Italy): initial results. Quaternary Science Reviews 18, 961-976.

Brauer, A., Mingram, J., Frank, U., G. unter, C., Schettler, G., Wulf, S., Zolitschka, B., Negendank, J.F.W., 2000. Abrupt environmental oscillations during the Early Weichselian recorded at Lago Grande di Monticchio, southern Italy. Quaternary 
International 73/74, 79-90.

Bronk Ramsey, C., 1999. Oxcal. radiocarbon calibration and stratigraphic analysis program. Research Laboratory for Archaeology, Oxford (Oxford University). http://www.rlaha.ox.ac.uk/orau/oxcal.html

Buck, C.E. \& Blackwell, P.G., 2004. Formal statistical models for estimating radiocarbon calibration curved. Radiocarbon, 46, 1093-1102.

Buck, C.E., Kenworthy, J.B., Litton, C.D., Smith, A.F.M., 1991. Combining archaeological and radiocarbon information: a Bayesian approach to calibration. Antiquity 65, 808-821.

Buck, C.E., Cavanagh, W.G., Litton, C.D., 1996. Bayesian Approaches to Interpreting Archaeological Data. John Wiley, Chichester.

Buck, C.E., Christen J.A., 1998. A novel approach to selecting samples for radiocarbon dating. Journal of Archaeological Science 24, 303-310.

Buck, C.E., Millard, A.R. (eds.), 2004. Tools for Constructing Chronologies: Crossing Disciplinary Boundaries. Lecture Notes in Statistics 177, Springer-Verlag, Heidelberg.

Burr, G.S., Beck, J.W., Taylor, F.W., Recy, J., Edwards, R.L., Cabioch, G., Correge, T., Donohue, D.J., O’Malley, J.M., 1998. A high-resolution radiocarbon calibration between 11,700 and 12,400 calendar years B.P. derived from Th-230 ages of corals from Esperita Santo Island, Vanuatu. Radiocarbon 40, 1093-1105.

Calanchi, N., Dinelli, E., Gasparotto, G., Lucchini, F., 1996. Etnean tephra layers in Albano Lake and Adriatic Sea cores: new findings of Y1-layer in the central Mediterranean area. Acta Vulcanologica 8, 7-13.

Calanchi, N., Cattaneo, A., Dinelli, E., Gasparotto, G., Lucchini, F., 1998. Tephra layers in Late Quaternary sediments of the central Adriatic Sea. Marine Geology 149, 191209.

Christen, J.A., Clymo, R.S., Litton, C.D., 1995. A Bayesian approach to the use of ${ }^{14} \mathrm{C}$ dates in the estimation of the age of peat. Radiocarbon 37, 431-441. 
Chiu, T., Fairbanks, R.G., Mortlock, R.A. \& Bloom, A.L., 2005. Extending the radiocarbon calibration beyond 26,000 years before present using fossil corals. Quaternary Science Reviews 24, 1797-1808.

Dansgaard, W., Johnsen, S.J., Clausen, H.B., Dahl-Jensen, D., Gundestrup, N.S., Hammer, C.U., Hvidberg, C.S., Steffensen, J.P., Sveinbjörnsdottir, A.E., Jouzel, J., Bond, G., 1993. Evidence for general instability of past climate from a 250-kyr icecore record. Nature 364, 218-220.

Davies, S.M., Turney, C.S.M., Lowe, J.J., 2001. Identification and significance of a visible, basalt-rich Vedde Ash layer in a Late-glacial sequence on the Isle of Skye, Inner Hebrides, Scotland. Journal of Quaternary Science 16, 99-104.

Davies, S.M., Branch, N.P., Lowe, J.J., Turney, C.S.M., 2002. Towards a European tephrochronological framework for the Last Termination and early Holocene. Philosophical Transactions of the Royal Society of London, ser. A., 360, 767-802.

Davies, S.M., Bohncke, S.J.P., Hoek, W.Z., Lowe, J.J., Pyne-O’Donnell, S., Turney, C.S.M., 2004. Detection of Late-glacial distal tephra layers (cryptotephras) in The Netherlands. Boreas 34, 123-135..

Dellino, P., Isaia, R., Volpe, La L., and Orsi, G. 2001. Statistical analysis of textural data from complex pyroclastic sequences: implications for fragmentation processes of the Agnano-Monte Spina Tephra (4.1 ka), Phlegraean Fields, southern Italy. Bulletin of Volcanology 63, 443-461.

Dellino, P., Isaia, R., Volpe, La L., and Orsi, G,. 2004. Interaction between particles transported by fallout and surge in the deposits of the Agnano-Monte Spina eruption (Campi Flegrei, Southern Italy). Journal of Volcanology and Geothermal Research 133, 193-210.

Di Vito, M.A., Isaia, R., Orsi, G., Southon, J., de Vita, S., D’Antonio, M., Pappalardo, L. \& Piochi, M., 1999. Volcanism and deformation since 12,000 years at the Campi Flegrei caldera (Italy). Journal of Volcanology and Geophysical Research 91, 221-246. 
Eiríksson, J., Knudsen, K.L., Haflidason, H., Henrikson, P., 2000. Late-glacial and Holocene palaeoceanography of the North Atlantic Shelf. Journal of Quaternary Science 15, 23-42.

Eiríksson, J., Larsen, G., Knudsen, K.L., Heinemeier, J., Simonarson, L.A., 2004. Marine reservoir age variability and water mass distribution in the Iceland Sea. Quaternary Science Reviews 23, 2247-2268.

Erlenkauser, H., 1979. A thermal diffusion plan fro radiocarbon isotope enrichment from natural samples. In: Berger, R., Suess, H.E. (Eds.), Radiocarbon Dating. University of California Press, Berkeley, 216-237.

Friedrich, M., Kromer, B., Kaiser, K.F., Spurk, M., Hughen, K.A., Johnsen, S.J., 2001. High-resolution climate signals in the Bølling-Allerød Interstadial (Greenland Interstadial 1) as reflected in European tree-ring chronologies compared to marine varves and ice-core records. Quaternary Science Reviews 20, 1223-1232.

Geyh, M.A., Schleicher, H., 1990. Absolute Age Determination: Physical and Chemical Dating Methods and their Application, Springer-Verlag, Berlin.

Goodfriend, G.A., Flessa, K.W., 1997. Radiocarbon reservoir ages in the Gulf of California: roles of upwelling and flow from the Colorado River. Radiocarbon 39, 139-148.

Haflidason, H., Eiríksson, J. and van Krefeld, S., $\quad 2000 . \quad$ The tephrochronology of Iceland and the North Atlantic region during the Middle and Late Quaternary: a review. Journal of Quaternary Science 15, 3-22.

Horwell, C.J., Finoglio, I., Ragnarsdottir, K.V., Sparks, R.S.J. and Fubini, B., 2003. Surface reactivity of volcanic ash from the eruption of Soufrière Hills volcano, Montserrat, West Indies with implications for health hazards. Environmental Research 93, 202-215.

Hughen, K.A., Overpeck, J.T., Lehman, S.J., Kashgarian, M., Southon, J., Peterson, L.C., Alley, R., Sieman, D.M., 1998a. Deglacial changes in ocean circulation from an extended radiocarbon calibration. Nature 391, 65-68. 
Hughen, K.A., Overpeck, J.T., Lehman, S.J., Kashgarian, M., Southon, J., Peterson, L.C., 1998b. A new ${ }^{14} \mathrm{C}$ calibration data set for the Last Deglaciation based on marine varves. Radiocarbon 40, 483-494.

Hughen, K., Lehman , S., Southon, J., Overpeck, J., Marchal, O., Herring, C., Turnbull, J., 2004. ${ }^{14} \mathrm{C}$ activity and global carbon cycle changes over the past 50,000 years. Science 303, 202-207.

Hunt, J. B. \& Hill, P. G., 2001. Tephrological implications of beam size- sample size effects in electron microprobe analysis of glass shards. Journal of Quaternary Science 16(2): 105-117.

Hutchinson, I., James, T.S., Reimer, P.J., Bornhold, B.D., Clague, J.J., 2004. Marine and limnic radiocarbon reservoir corrections for studies of late- and postglacial environments in Georgia Basin and Puget Lowland, British Colmbia, Canada and Washington, USA. Quaternary Research 61, 193-203.

Kanfoush, S.L., Hodell, D.A., Charles, C.D., Guilderson, T.P., Mortyn, P.G., Ninnemann, U., 2000. Millennial-scale instability of the Antarctic ice sheet during the Last Glaciation. Science 288, 1815-1818.

Keller, J., Ryan, W.B.F., Ninkovich, D., Altherr, R., 1978. Explosive volcanic activity in the Mediterranean over the past 200,000 years as recorded in deep-sea sediments. Bulletin of the Geological Society of America 89, 591-604.

Kilian, M.R., van Geel, B., Blaauw, M., van der Plicht, J., 2000. ${ }^{14}$ C AMS wiggle matching of raised bog deposits and models of peat accumulation. Quaternary Science Reviews 19, 1011-1033.

Kitagawa, H, van der Plicht, J., 1998. Atmospheric radiocarbon calibration to 45,000 yr BP: Late Glacial fluctuations and cosmogenic isotope production. Science 279, 1178-90.

Kitagawa, H., van der Plicht, J., 2000. Atmospheric radiocarbon calibration beyond 11,900 cal BP from Lake Suigetsu laminated sediments. Radiocarbon 42, 369-380. 
Kromer, B. et al., 2004. Late glacial ${ }^{14} \mathrm{C}$ ages from a floating 1382-ring pine chronology. Radiocarbon 46, 1203-1209.

Lowe, J. J. \& Walker, M. J. C., 2000. Radiocarbon dating the last glacial- interglacial transition: (ca. $14-9{ }^{14} \mathrm{C}$ ka BP) in terrestrial and marine records: the need for new quality assurance protocols. Radiocarbon 42, 53-68.

Lowe, J.J., Walker, M.J.C., Scott, M., D.D. Harkness, Bryant, C., Davies, S.M., 2004. A coherent high-precision radiocarbon chronology for the Lateglacial sequence at Sluggan Bog, Co. Antrim, Northern Ireland. Journal of Quaternary Science 19, 147158.

Mangerud, J., Guilliksen, S., 1975. Apparent radiocarbon ages of recent marine shells from Norway, Spitzbergen and Arctic Canada. Quaternary Research 5, 263-273.

Muscheler, R., Beer, J., Wagner, G., Laj, C., Kissel, C., Raisbeck, G.M., Yiou, F., Kubik, P.W., 2004. Changes in the carbon cycle during the last deglaciation as indicated by the comparison of ${ }^{10} \mathrm{Be}$ and ${ }^{14} \mathrm{C}$ records. Earth and Planetary Science Letters 219, 325-340.

North Atlantic Ice Core Project Members, 2004. High-resolution record of Northern Hemisphere climate extending into the last interglacial period. Nature 431, 147-151.

Oldfield, F., Asioloi, A., Accorsi, C.A., Mercuri, A.M., Juggins, S., Langone, L., Rolph, T., Trincardi, F., Wolff, G., Gibbs, Z., Vigliotti, L., Frignani, M., van der Post, K and Branch, N., 2003. A high resolution late Holocene palaeo-environmental record from the central Adriatic Sea. Quaternary Science Reviews 22, 319-342.

Paterne, M., Guichard, F., Labeyrie, J., 1988. Explosive activity of the south Italian volcanoes during the past 80,000 years as determined by marine tephrochronology. Journal of Volcanology and Geothermal Research 34, 153-172.

Paterne, M., Labeyrie, J., Guichard, F., Mazaud, A., Maitre, F., 1990. Fluctuations of the Campanian explosive volcanic activity (south Italy) during the past 190,000 years as determined by marine tephrochronology. Earth and Planetary Science Letters 98, 166-174. 
Pollard, A.M., Blockley, S.P.E., Ward, K.R., 2003. Chemical alteration of tephra in the depositional environment: theoretical stability modeling. Journal of Quaternary Science 18, 385-394.

Pollard, A.M., Blockley, S.P.E., Lane, C.S. (in press). The chemical correlation of microtephras: numerical analysis of geochemical data. Applied Geochemistry.

Pyne-O’Donnell, S. D.F., 2005. The factors affecting the distribution and preservation of microtephra particles in Lateglacial lake sediments. PhD Thesis, University of London, unpublished.

Rasmussen, S.O., Andersen, K.K., Svensson, A.M. et al. (in press) A new Greenland ice core chronology for the last glacial termination. Journal of Geophysical Research.

Reimer, P.J., Reimer, R.W., 2001. A marine reservoir correction database and on-line interface. Radiocarbon 43, 461-464.

Reimer, P.J. et al., 2004. IntCal04 Terrestrial Radiocarbon Age Calibration, 0-26 cal kyr BP. Radiocarbon 46, 1029-1058.

Schramm, A., Stein, M., Goldstein, S.L., 2000. Calibration of the ${ }^{14} \mathrm{C}$ time scale to $>40$ ka by ${ }^{234} \mathrm{U}^{230} \mathrm{Th}$ dating of Lake Lisan sediments (last glacial Dead Sea). Earth and Planetary Science Letters 175, 27-40.

Siani, G., Paterne, M., Arnold, M., Bard, E., Métivier, B., Tisnerat, N., Bassinot, F., 2000. Radiocarbon reservoir ages in the Mediterranean Sea and Black Sea. Radiocarbon 42, 271-280.

Siani, G., Paterne, M., Michel, E., Sulpizio, R., Sbrana, A., Arnold, M., Haddad, G., 2001. Mediterranean Sea Surface Radiocarbon Reservoir Age Changes Since the Last Glacial Maximum. Science 294, 1917-1920.

Siani, G., Sulpizio, R., Paterne, M., Sbrana, A., 2004. Tephrostratigraphy study for the last $18,000{ }^{14} \mathrm{C}$ years in a deep-sea sediment sequence for the South Adriatic. Quaternary Science Reviews 23, 2485-2500. 
Sikes, E.L., Samson, C.R., Guilderson, T.P., Howard, W.R., 2000. Old radiocarbon ages in the southwest Pacific Ocean during the last glacial period and deglaciation. Nature 405, 555-558.

Taylor, R.E., Kra, R. and Long, A. (Eds.), 1992. Radiocarbon After Four Decades: an interdisciplinary Perspective. Springer-Verlag, New York.

Telford, R.J., Heegaard, E., Birks, H.J.B., 2004a. All age-depth models are wrong: but how badly? Quaternary Science Reviews 23, 1-5.

Telford, R.J., Heegaard, E., Birks, H.J.B., 2004b. The intercept is a poor estimate of a calibrated radiocarbon age. The Holocene 14, 296-298.

Trincardi, F., Asioli, A., Cattaneo, A., Correggiari, A., Langone, L., 1996. Stratigraphy of the late-Quaternary deposits in the central Adriatic basin and the record of shortterm climatic events. Memorie Istituto Italiano di Idrobiologia 55, 39-70.

Turney, C.S.M., Lowe, J.J., 2001. Tephrochronology. In: Last, W.M., Smol, J.P. (Eds.), Tracking Environmental Change Using Lake Sediments, Vol. 1: Basin Analysis, Coring and Chronological Techniques. Kluwer Academic Publishers, Dordrecht, The Netherlands, 451-471.

Turney, C.S.M., Harkness, D.D., Lowe, J.J., 1997. The use of micro-tephra horizons to correlate Lateglacial lake sediment successions in Scotland. Journal of Quaternary Science 12, 525-531.

Turney, C.S.M., Coope, G.R., Harkness, D.D., Lowe, J.J., Walker, M.J.C.W., 2000. Implications for the precise dating of Wisconsinan (Weichselian) lateglacial events of systematic radiocarbon age differences obtained from terrestrial plant macrofossils from a site in SW Ireland. Quaternary Research 53, 114-121.

Utzmann, A., Hansteen, T. and Schminke, H.-U., ２002. Trace element mobility during sub-seafloor alteration of basaltic glass from Ocean Drilling Program site 953 (off Gran Canaria). International Journal of Earth Sciences 91, 661-679. 
Van Geel, B., Mook, W.G., 1989. High-resolution ${ }^{14} \mathrm{C}$ dating of organic deposits using natural atmospheric ${ }^{14} \mathrm{C}$ variations. Radiocarbon 31, 151-155.

Van Geel, B., van der Plicht, J., Renssen, H., 2003. Major $\Delta^{14} \mathrm{C}$ excursions during the late glacial and early Holocene: changes in ocean ventilation or solar forcing of climate change? Quaternary International 105, 71-76.

Voelker, A.H.L., Sarnthein, M., Grootes, P.M., Erlenkauser, H., Laj, C., Mazaud, A., Nadeau, M-J., Schleicher, M., 1998. Correlation of marine ${ }^{14} \mathrm{C}$ ages from the Nordic seas with the GISP2 isotope record: implications for radiocarbon calibration beyond 25 ka BP. Radiocarbon 40, 517-534.

Waelbroek, C., Duplessy, J.C., Michel, G., Labeyrie, L., Paillard, D., Duprat, J., 2001. The timing of the last deglaciation in the North Atlantic climatic records. Nature 412, 724-727.

Walker, M.J.C., Bryant, C., Coope, G.R., Harkness, D.D., Lowe, J.J., Scott, E.M., 2001. Towards a radiocarbon chronology for the Late-glacial in Britain. Radiocarbon 43, 1007-1019.

Walker, M.J.C., Coope, G.R., Sheldrick, C., Turney, C.S.M., Lowe, J.J., Blockley, S.P.E., Harkness, D.D., 2003. Devensian Lateglacial environmental changes in Britain: a multi-proxy record from Llanilid, South Wales, UK. Quaternary Science Reviews 22, 475-520.

Wulf, S., Kraml, M., Brauer, A., Keller, J., Negendank, J.F.W., 2004. Tephrochronology of the 100 ka lacustrine sediment record of Lago Grande di Monticchio (southern Italy). Quaternary International 122, 7-30.

Yokoyama, Y., Esat, T.M., Lambeck, K., Fifield, L.K., 2000. Last Ice Age millennial scale climate changes recorded in the Huon Peninsula corals. Radiocarbon 42, 383402. 